\title{
الاستقصاي التأملى القائم على بحوث العمل ودوره في تنمية التحصيل \\ والتفكير التأملى فى مادة العلوم لدى تلاميذ المرحلة الإبتدائية
}

\section{يمنى ايمالب محمود إبراهيم أبو الحنين}

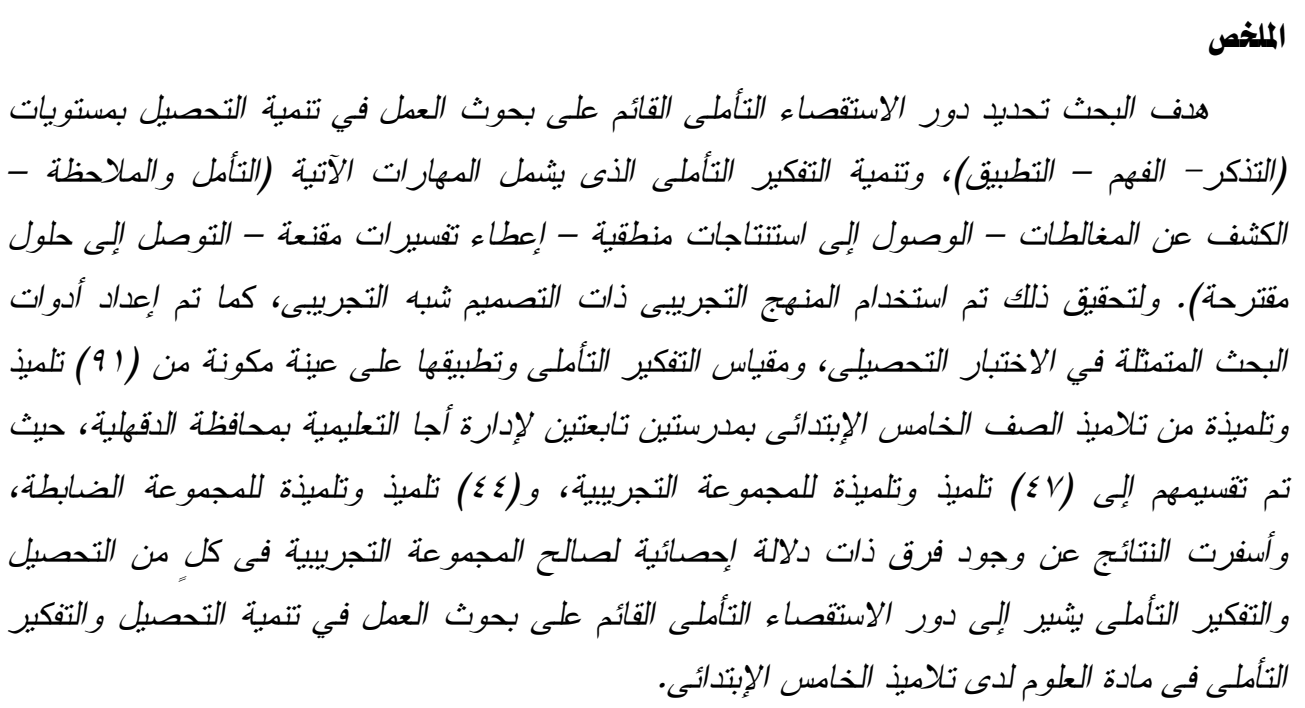

Abstract:

The research aimed at determining the role of Action Research based- Reflective Inquiry in developing both achievement at levels of (Knowledge - comprehension - application) and Reflective thinking with these skills: (Meditation and Observation - Mistakes detection - Access to conclusions - Giving convincing explanations- Develop proposed solutions). To achieve that, the experimental method with the quasi-experimental design was used, achievement test, and Scale of reflective thinking were prepared, these tools were applied on a sample of (91) students of the $5^{\text {th }}$ grade primary pupils distributed into two schools of educational Aga district at Dakahlia governorate, however, (47) pupils for the experimental group and (44) pupils for the control group. The results showed that there is a statistically significant difference in favor of the experimental group in both academic achievement and reflective thinking. So, these results indicated the role of action research - based - reflective inquiry in developing achievement and reflective thinking. 


\section{مقدمة:}

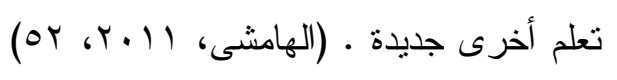

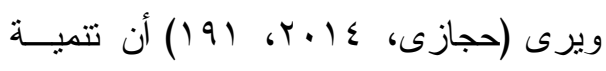

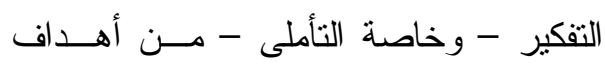
تدريس العلوم وذلك على اعتبار أن التفكيـــر

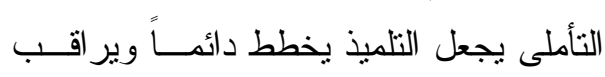
ويقيم أسلوبه فى العمليات و الخطوات التـى لئى

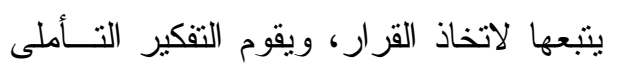

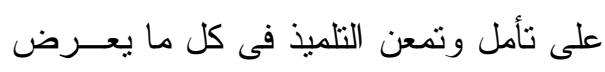
عليهم من معلومات، وهذا بدوره ييقى أنــراً

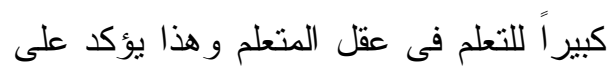
التعلم ذى المعنى وهو جوهر ما تركز عليه استر اتيجيات التدريس الحديثة فى العلوم • ومن أكثــر اســتر اتيجيات التـدريس

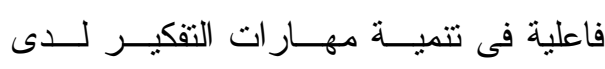

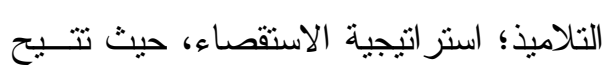

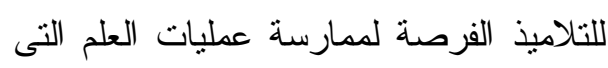
تتضمنها الطريقة العلمية فى البحث، و التفكير فيسلك سلوك العلماء للبحث عــن المعرفــة،

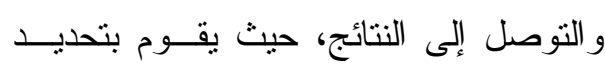

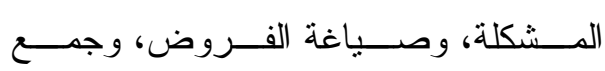
المعلومات، واختار صحتها، للوصول إلـى وصى وحنى

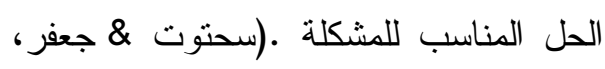

$$
\text { (1) ، Y . I s }
$$

و لإستر اتيجية الاستقصاء التأملي فعالية في دفع الطلاب إلى التعمق في المنهج العلمى لإنى مما يؤدى إلى تحسين اكتساب المفاهيم العلمية
إن العصر الحالى بشهـ تقدماً علميــاً

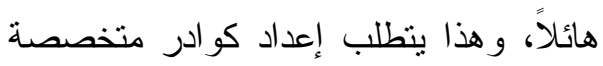

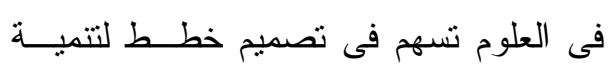

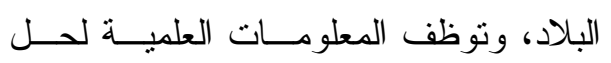

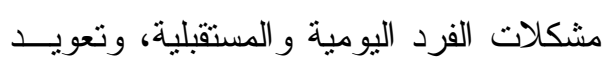
النشئ الجديد على التقكير العلمى فى مو اجهة ظروف الحياة، هذا ما جعل لتدريس العلــوم

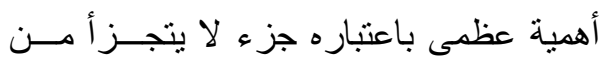
الثقافة الإنسانية، حيث تتمو مهار ات الطلاب

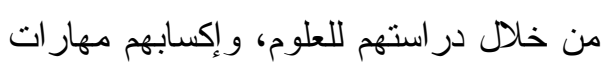
التفكير العلمى كالاستتناج، و التحليل و غير ها دها

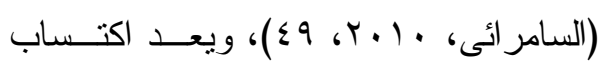

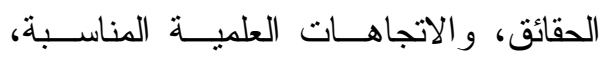
و المهار ات عقلية التى يمكن أن تجعـل مــن التهن

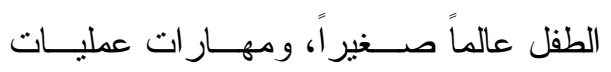

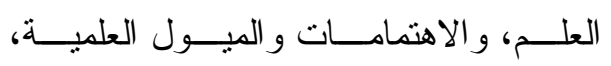

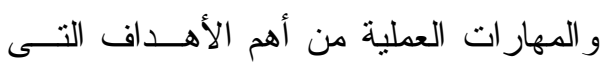
يسعى تدريس العلوم إلى تحقيقها عند طلاب الهم الهن

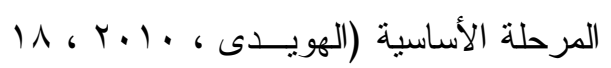
(r) و لاكتساب المفاهيم و الحقائق للوصول

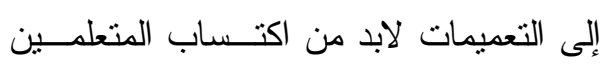

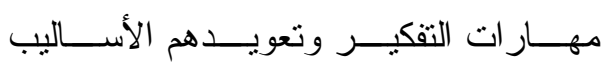
الصحيحة فى ذلك، من خلال ربط مــا تـم

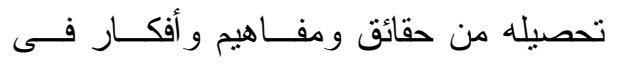

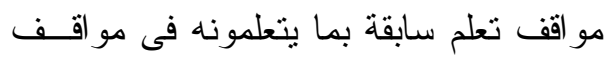


الأخلاقية و العملية، بل يعتمد أيسـضاً علــى

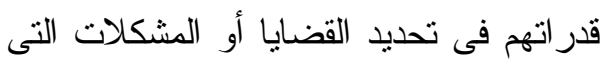

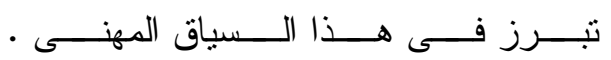
(Day\&Leith, 2000, 183)، وقد أجريت العديد من الدراسات في مجال العلوم التـي ولتي

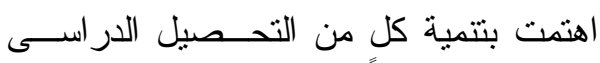
و التفكير التأملى لدى التلاميذ باستخدام بحوث من التئ

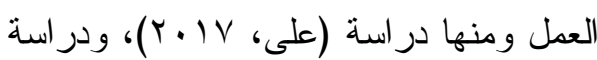

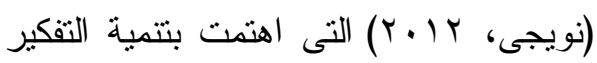

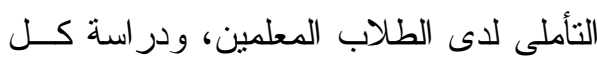

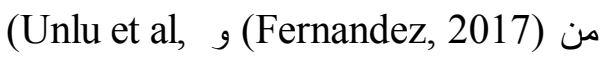

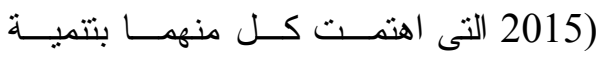
التحصيل الدر اسى باستخدام التعلم القائم على لألى الاستقصاء باستخدام بحث العمل .

مما سبق يتـــح أهميــة كـلـل مــن

الاستقصاء التأملى وبحوث العمل في نتميــة التحصيل ومهار ات التفكير التــأملى، لـــللك فئل يسعى البحث الحالى للامج بين الاستة صـاء التأملى وبحوث العمل لتحديد دوره فى نتمية التحصيل و التفكير التأملى .

الإحساس بالشكلة: يرجع إجراء هذه الدراسة إلى عدة أســباب ومنها :

ا - اعتماد المدرسين وخاصــة مدرسـى لهـ العلوم على طريقة التدريس التقليديـــة فى تقديم المنهج الدراسى دون التتوع

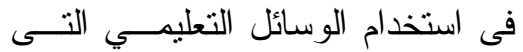

و الفيزيائية، وتتمية الإتجاهات العلمية لــديهم

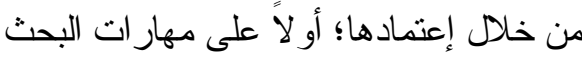
للوصول إلي الغاية العلمية ( تحديد المشكلة،

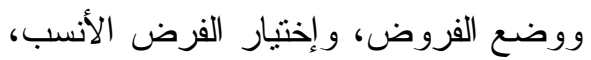
ثم الوصول إلى الحلـــول )، وثانيــا التعــــيم

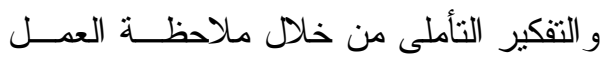
الذي قام به و توليد معنى من هذه الملاحظة،

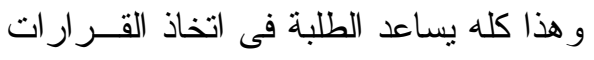

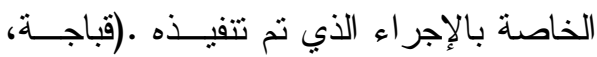

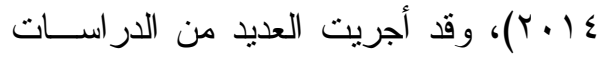

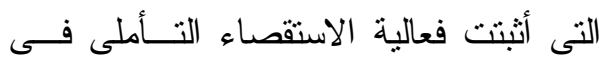
تتمية الجو انب المختلف لدى التلاميذ فى مادة

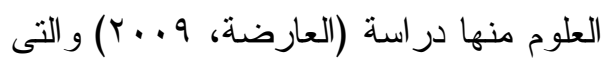
أثنتت فعالية الاستقصاء التأملى فى تحــسين فهم الفيزياء، وتعديل التصورات حول طبيعة التطاه

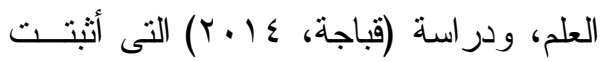
فعالية الاستقصاء الثأملى فى اكتساب المفاهيم

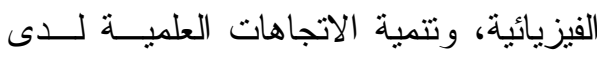

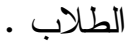
وللاستقصاء عن الأساليب التى يمكن أن تنساعد فى تحسين ممارســات الطــلاب

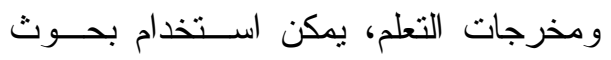
العمل التى تكسب المعلمين نظرة ثاقبة فـى ممارساتهم الخاصة فــى العمليــة التعليميــة وذلك من خلال عمليتــى التأمــل، و التقبــيم (Chain et al, 2013, 59)، فبحوث العمل لا تعتمد فقط على ممارسة المعلمين للمعايير 


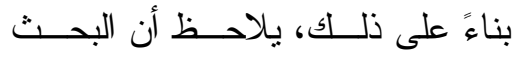

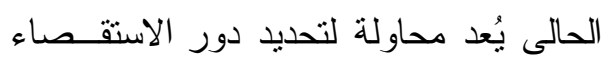
التأملى القائم على بحوث العمل فــى تتميــة التحصبل و التفكير التأملى فى مـــادة العلــوم لدى تلاميذ المرحلة الإبتدائية.

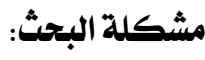

إن الغالبية العظمى مــن المدرســين يعتمدون فى تدريسهم على الطريقة التقليدية

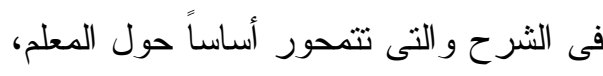
ومن ناحية أخرى هنالك الكثير من معلمـى العلوم غير مؤهلين لتدريس العلــوم، نظـــراً لعدم السعي لتحسين ممارســـاتهم التذريــسية

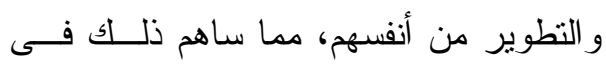

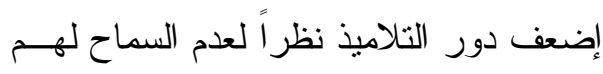
بالمشاركة أثثاء الحصة، حيث يقتصر دور هم فقط على تلقى المعلومات وحفظها كما هــى دهـ مجردة، كل ذللك أدى إلى نـسيان التلاميــذ

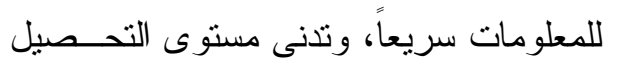

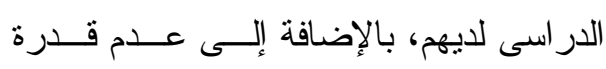

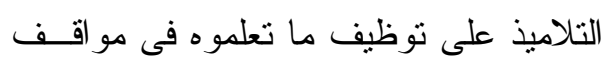

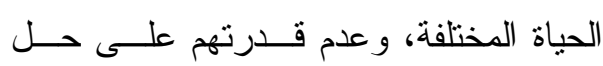
المشكلات التى قد تواجههم أثتـــاء دراســــة العلوم، و التى من أهم أهدافها نتمية مهار ات التفكير المختلفة وخاصةً التفكير التأملى لدى اهیى

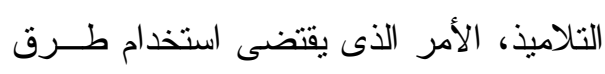

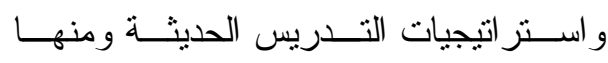
الاستقصاء التأملى القائم على بحوث العمل،
تعزز من العملية التعليمية وتحــسنها،

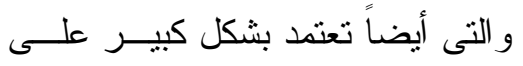
المعلم وجعله محور العملية التعليميــة بدلاً من التلميذ حيث تشجع التلامبـذ على التلقين و الحفظ و الصم للمعلومات دون فهمها وتطبيقها فى مواقف الحياة المختلفة. r- افتقار مناهج العلوم إلى تتمية مهار ات

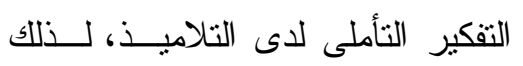
اهتمت العديد من الدراسات بتتمية كل

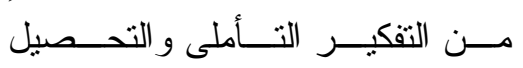
الدراسى لــدى التـلاميـــذ باســتخدام الاستر اتيجيات التدريسية المختلفة منها

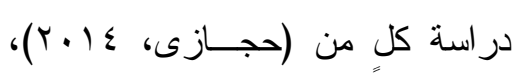

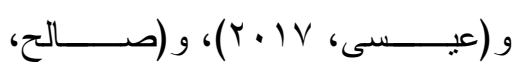
r)

بـ الحاجــة إلــى تحــسين الممارســـات التدريسية، و التطوير المهنى للمعلمين،

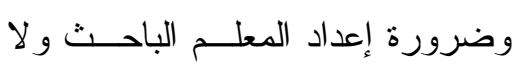
يتأتى ذلك إلا مــن خــلال ممارســة بحوث العمل، لذلك اهتمث العديد من

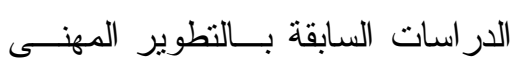
للمعلمين من خلال نلاك النوعية مــن

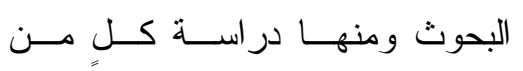
،(Huduk, 2013) ،(Vaiyavutjamai et al, 2012), . (Töman, 2017)و 
ا - توجد فروق ذات دلالة إحصائية عنـــ

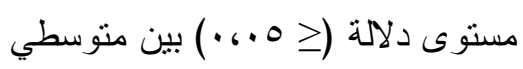

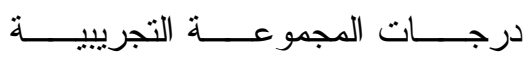

و المجمو عة الــضـابطة فــي التطبيــق

البعدي للاختبار التحــصيلى لـصالح

المجمو عة التجريبية.

r- توجد فروق ذات دلالة إحصائية عنــــ

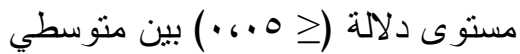

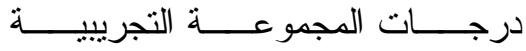

و المجمو عة الــضـابطة فــي التطبيــق

البعدي لمقيــاس مهـــار ات التفكيــر

التأملي لصالح المجمو عة التجريبية .

"- توجد علاقة ارتباطية دالة عند مستوى

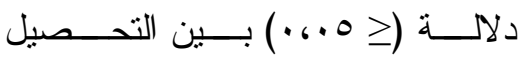

الدراسي ومهار ات التفكير التأملي لدى

تلامبذ الصف الخامس الابتــــئي فـى

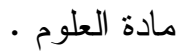

ع - يمكن أن تؤدى صحائف التفكــر إلــى

تحسين ممارسات المعلم داخل الفــصل

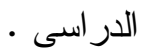

0- يمكن أن تؤدى صحائف التفكــر إلــى

تحسين ممارسات المتعلم داخل الفصل

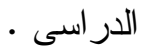

أهمية البحث:

في ضوء ما هو متوقع للبحث الحالي مـن

نتائج يمكن لله أن يسهم فيما يلي:
ومن ثم أمكن تحديد مشكلة البحث الحالى من

خلال الإجابة على السؤال الرئيسى التالى "ما

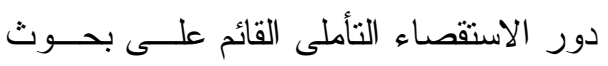

العمل فى تتمية كل من التحصيل و التفكيـر

النأملى لاى تلاميذ المرحلة الإبندائية ؟".

\section{وتفرع من السؤال الرئيس الأسئلة التالية :}

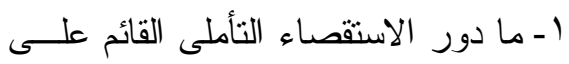

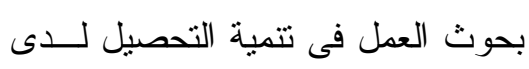

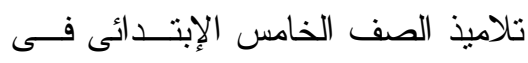

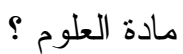

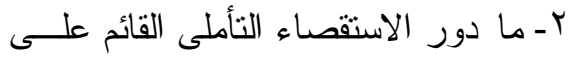

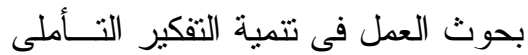

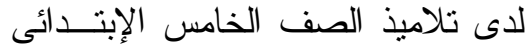

فى مادة العلوم ؟

ז- إلى أى مدى توجد علاقة ارتباطية بين

التحصيل الدراسى ومهارات التفكيـر

التأملى لدى تلاميذ الـصف ومهي الخـامس

الإبتدائى فى مادة العلوم ؟

ـ - ما دور صحائف التفكر فـى تحسسين

ممارسات المعلم داخل الفصل الدراسى تلى

?

هـ ما دور صحائف التفكر فـى تحسين

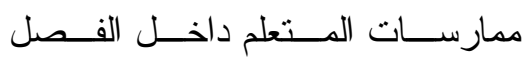

الدراسى ؟ إن

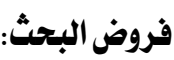

تمثلت فروض البحث فيما يلي: 
\&- بالنسبة للمتخصصين فى المناهج :

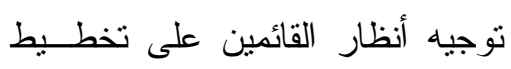

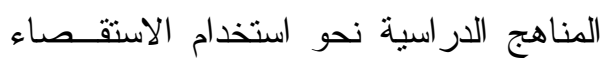

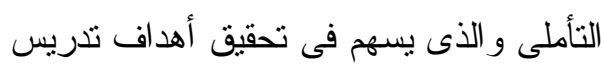

العلوم بحيث يجعله يقوم على الفهم و التطبيق وربط المفاهيم بالحياة اليومية وحل مشكلاتها

عبر البحث و التأمل و التجريب و الاسنتناج .

مواد وأدوات البحث:

أولاً: مواد المعالجة التجريية:

1 - دليل المعلم لوحدة التجريــب. (مـنـ

إعداد الباحثة)

r- كر اسة نشاط التلميــذ. (مسـن إعــداد

الباحثة)

ثنانياً: الأدوات البحثية:

1- اختبار تحـــيلي لمحتــوى الوحسـدة

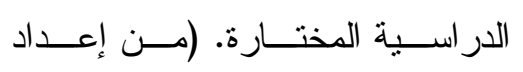

الباحثة)

r- مقياس التقكير التأملى. (مــن إعــداد

الباحثةة)

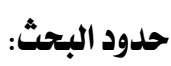

1. حدود مكاتية: مدرسة الثهيد صــلاح

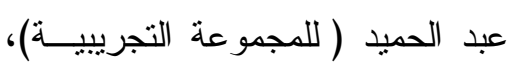

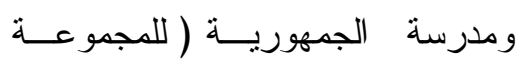

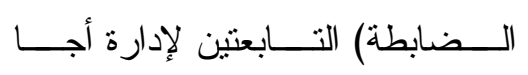

التعليمية بمحافظة الدقهلية.
1- بالنسبة للتلاميذ :

مساعدة المتعلمين على تتمية مهار ات

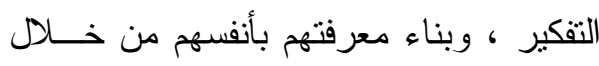

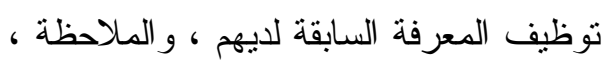

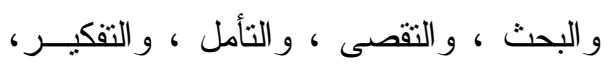

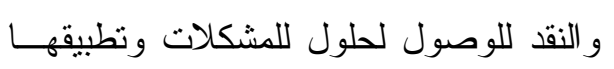

فى المو اقف الجديدة .

r- بالنسبة للمعلم :

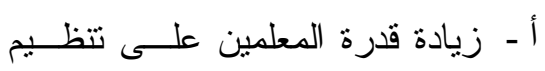

الوقت ، و إدارة الفصل، و واســتخدام

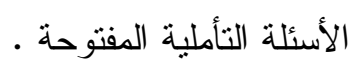

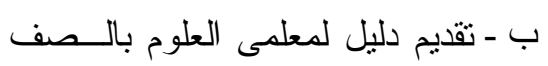

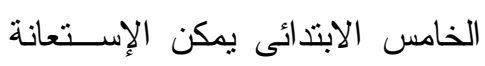

به فى تدريس وحدات مادة العلـــوم

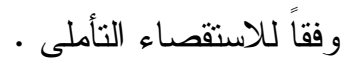

r- بالنسبة للعملية التعليمية و المجتمع :

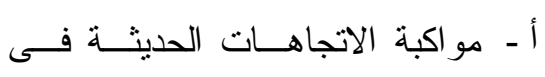

تدريس العلوم عن طريق اســتخدام

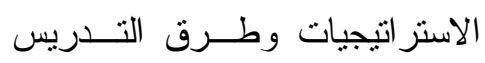

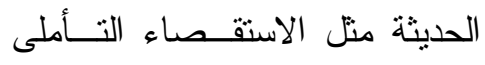

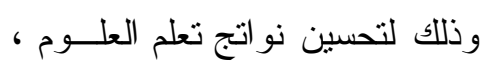

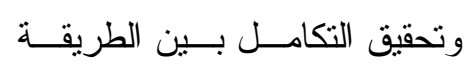

و المعرفة العلمية . ونائ

ب - التأكيد على أهمية إثـــر الك أوليــاء

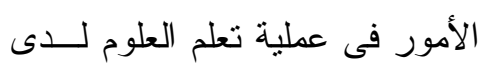

$$
\text { · أبنائهر }
$$


تكون مجتمع البحث من تلاميذ الصف

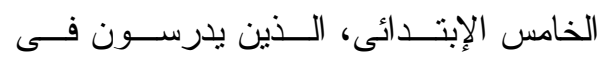

المدارس الحكومية لوز ارة التزبية و التعلــيم

التابعة لإدارة أجا التعليمية بمحافظة الدقهلية،

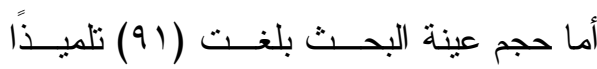

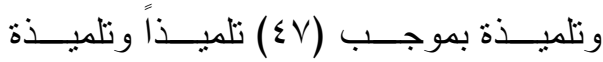

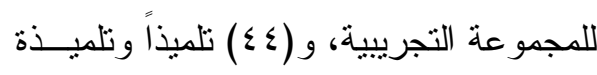
للمجمو عة الضابطة مصطلحات البحث:

يعرف الاستقصاء التـــأملى إجر ائيـاً بأنه: أحد طرق التذريس التىى تقــوم علــى وضع التلامبذ فى موقف مثير يمنل مـشكلة ما فى العلوم يدفعهم إلــى ربــــ معــارفهم السابقة بالمعرفة الجديدة، و إيجــاد علاقــات

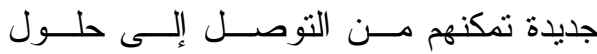
للمشكلة، وذلك من خلال تتفيذهم لمجموعــة من الأنشطة الاستقصائية التأملية بهدف تتمية تحصيل التلاميذ وكذلك مهـــار ات التفكيـر • التأملى لديهم

وتعرف بحوث العمل إجرائياً بأنهـــا:

أسلوب بحثى استقصائى يقوم علــى تأمسـل المعلم فى ممارساته التدريسية و المــثكلات التى تو اجهه أثناء التذريس ويسعى إلى حلها من خلال جمع البيانات وتحليلها فى ضــو

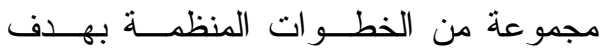
تحسين ممارساته التدريسية وكذلك مخرجات التعلم لدى طلابهه .
ץ. حدود زمنية: تم تطبيق البحث الحالي

خلال الفصل الدراسي الثاني للــصف

الخامس الإبتــدائى للعــام الدر اســـي

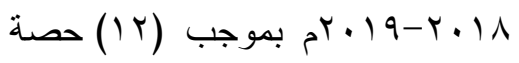
تم تدريسها لمدة (ع) شهر • r. حدود موضوعية: تمثلت المحــددات

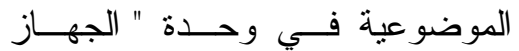
الدورى و الجهاز الإخر اجى" من كتاب العلوم للــصف الخــامس الإبتـــدائى للفصل الدر اسي الثاني لعــام 1 1 . r-

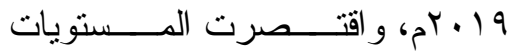
المعرفية للاختبار التحــصيلى علـى لـى مستويات (التذكر - الفهم - التطبيق)،

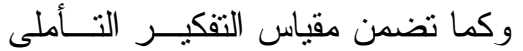
مهار ات الآتية : (التأمل و الملاحظة و الكثف عن المغالطات - و الوصول إلى استتاجات منطقيــة - و إعطــاء تفسير ات مقنعة - و التوصل إلى حلول مقترحة). منهج البحث: استخدم البحث الحالى: المنهج التجريبى ذو التـصميم شــبه التجريبـى للبحث للمجمــو عتين ( التجريبيـــة

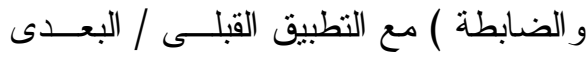
لأدوات البحث.

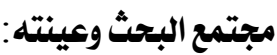


توظيف الاستقصاء التـــأملى فـــ تـــريس

$$
\text { العلوم : - نوطي }
$$

تكمن قيمة در اسة العلوم من خــلاد

الاستقصاء التأملي في إتاحة الفرصة للطالب دن من

للقيام بدور الباحث لكى يدرك كيفية تطــور

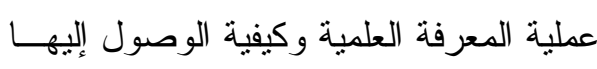
• هذا هو السبب في وجود بحث عن أفكـار

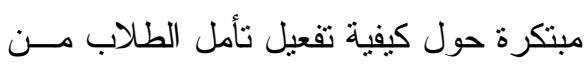

أجل التتفيذ الفعال لهذا النوع من الاستقصاء

‘(Dimova \& Kamarska, 2015, 37)

و الاستقصـاء التــأملى يعمـلـل علــى تحفيــز

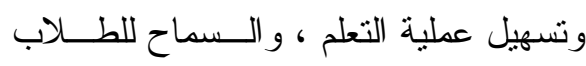

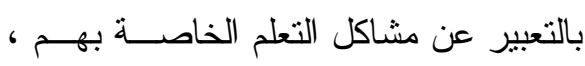

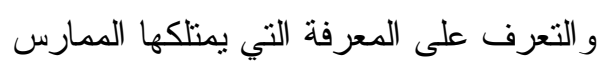
، و البحث عن ممارســات نــدريس بديلـــة

- (Chian et al, 2013, 67-68) ويثير (Hiebert et al, 1996, 19) إلـى أن الاستقصاء التأملى يسهم فيما يلى :

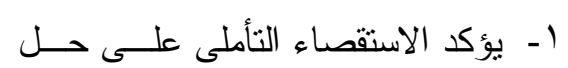

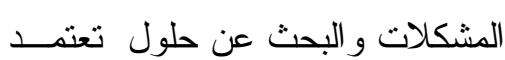

$$
\text { بقدر كبير على الابتكار - }
$$

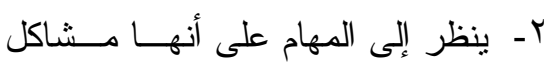

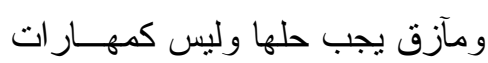

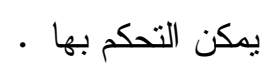

ويُعرف التحصيل الدراسي إجرائيـاً

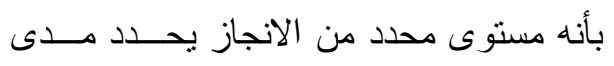

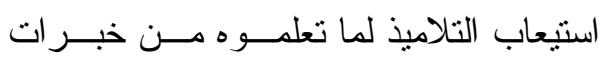

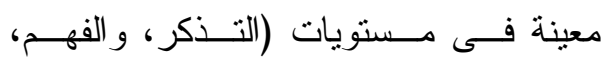

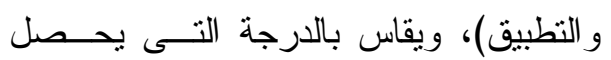

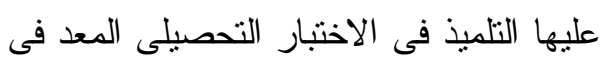
الدر اسة الحالية . كما يُعرف التفكير التــأملى إجرائيــاً بأنه نشاط عقلى يساعد المتعلم علــى از الـــة غموض موقف ما من خلال البحث و التقصى

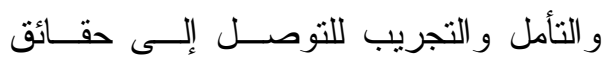
و استتناجات تمكنه من حل المشكلات ويقاس بالارجة النى يحصل عليها التلميذ فى مقياس التقكير التأملى المعد فى الدر اسة الحالية . الإطار النظري للبحث:

\section{المحور الأول: الاستقصاء التاملى وتدريس العلوم} تعريف الاستقصاء التأملى:

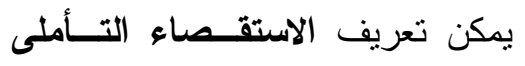
إجر ائياً بأنه: أحد طرق لتربـ التدريس التى تقــوم

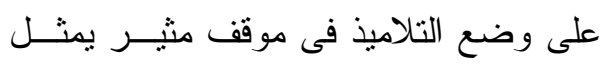

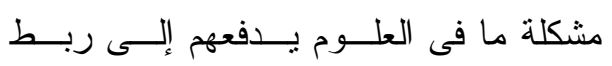

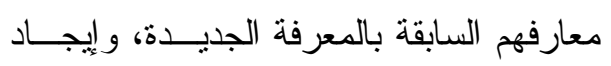
علاقات جديدة تمكنهم من التوصل إلى حلول للمشكلة، وذلك من خلال تتفيذهم لمجموعــة هونة من الأنشطة الاستقصائية التأملية بهرف تتمية تحصيل التلاميذ وكذللك مهــار ات التفكيــر التاملى لديهم 
و المشكلات التى تو اجهـــه أثتـــاء التــدريس ويسعى إلى حلها من خلال جمــع البيانــات

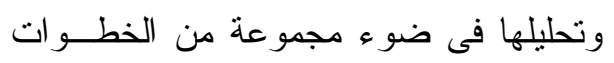
المنظمة بهدف تحسين ممارساته التنريسـية فئه وكذلك مخرجات التعلم لاى طلابه . خصائص بحوث العمل :

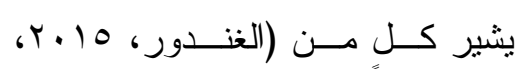
ع إلى أن من اهم خصائص البحث الإجر ائى : ا - دورى : بمعنى أنه يتم علــى شـــل

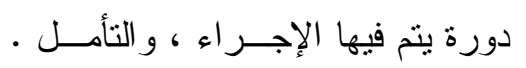

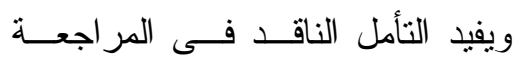

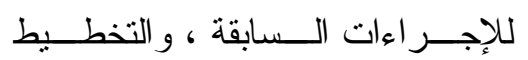

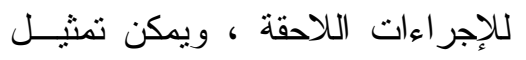
البحث الأجرائى على شــكل دورات

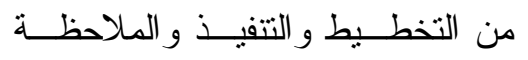

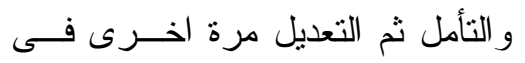
حالة وجود مستجدات أثناء العمل . r - تأملى : بمعنى أن الباحث يكون فـى

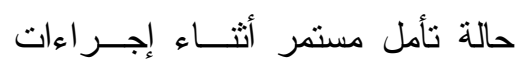

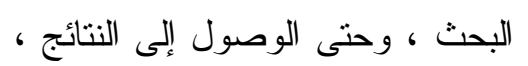

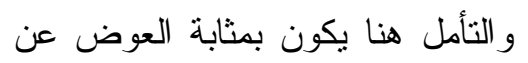

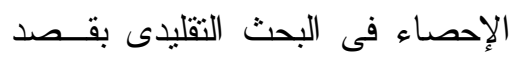

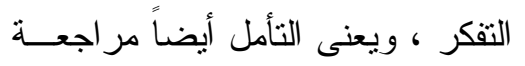

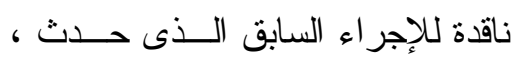

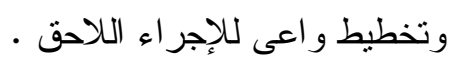

ب- ت تتبع التغذية الراجعــة حــول مــدى

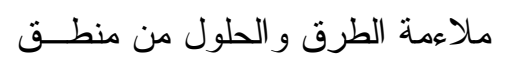
الموضو ع وليس من المعلم.

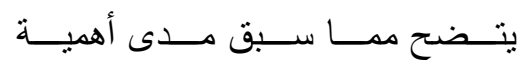
الاستقصاء التأملى فى جعل الطالب إيجابيـاً أثناء التعلم من خلال تأمله لأفكاره ومعرفته

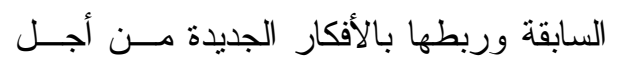
الوصول لحل ما يو اجهه من مشكلات أثتـــاء الموقف التعليمى خلال تدريس العلوم -

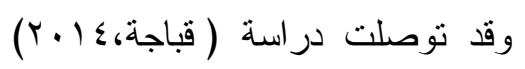
إلى فاعلية استر اتيجية الاستقصاء التأملى فى لثى اكتساب المفاهيم الفيزيائية وتتمية الاتجاهات

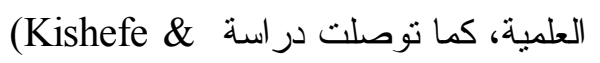
Abd El-khalik, 2002) بالاستقصاء الموجه الصريح و التأملي أكثـــر

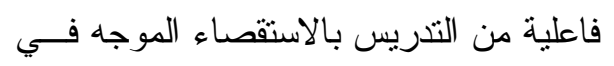

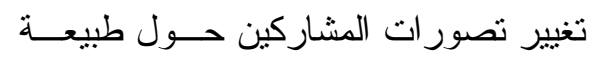
العلم، وأيضـاً توصلت در اســـة (العارضـــة،

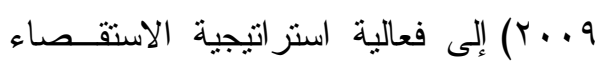
التأملى فى تحسين فهم الفيزيــاء، وتعـديل التصور ات حول طبيعة العلم .

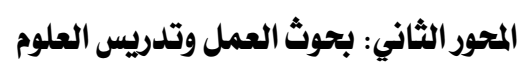
مفهوم بحوث العمل : يمكن تعريف بحوث العمـل إجرائيــاً

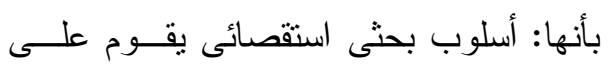
تأمسلـل المعلــم فــى ممارســـاته التدريــسية 


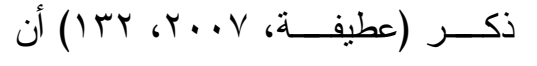

هناك بعــ الأدوات التــى مــن الممكـن

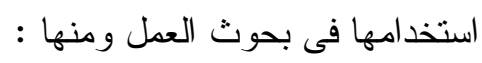

الــسجلات أو التــدوينات المكتوبـــــة

،التسجيلات السمعية و المرئية ، الملاحظـــة

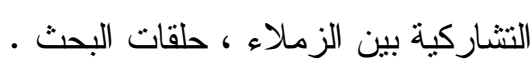

وقد استخدم البحث الحالى صــحائف

التفكر وهى أثنهر صور التدوينات المكتوبة

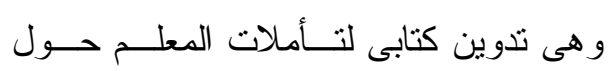

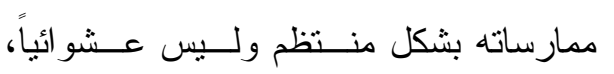

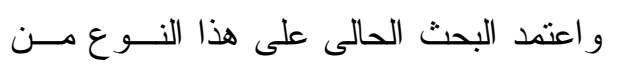
التدوينات لكلٍ من المعلم و المتعلم أســـبوعياً

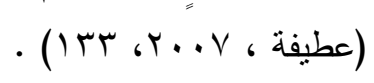

دور بحوث العمل فى تدريس العلوم :

إن الطريقة الوحيدة لنقل تعليم العلـــوم

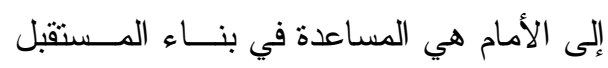
من خلال التطوير المهني المـستصر و الــذي لهي (Bianchi \& Feasey, يشمل بحوث العمل

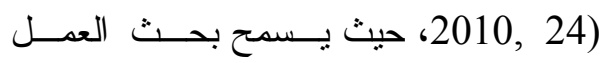

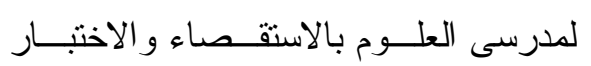
و التأمل في الإجر اءات التي يتخذونها لتقيــيم المناهج، وتأطير القرارات المحلية لإصـــلاح

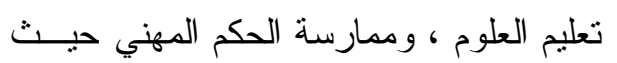

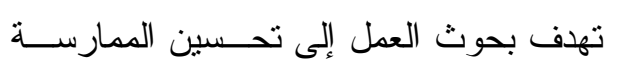

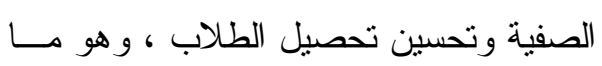
يتماثىى مع الإصلاحات التعليمية التي تدعو r- كيفى : بمعنى أن الباحث يتعامل مع

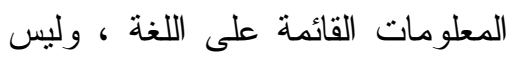
الأرقام كما هو متبع فـى البحــوث

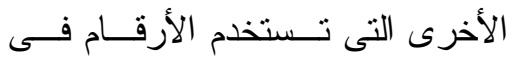
التحليل الإحصائى للبيانات ، و القصد الإنى فى ذلك الأمر هو إبعاد الباحث عـن

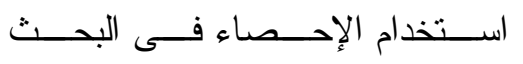
الإجرائى لصعوبة استخدامها ، ولكن الإهن الأكيد هو أن الإحصاء فــى تحليلهـــا للبيانات للبحث التقليدى او العلمى إنما

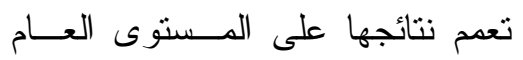

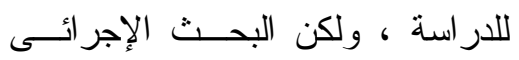

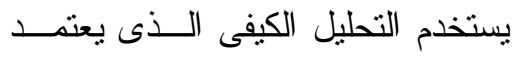

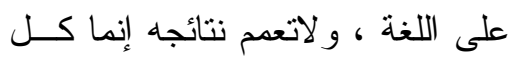

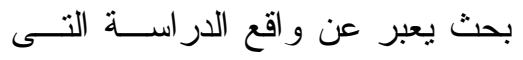
يعنيها فقط . ع- - مرن : بمعنى انه يتيح التعديلات أثناء

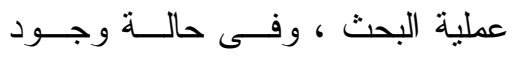
حالات طارئة . 0ـ تشاركى : حيث يشترك فيه الدارسين

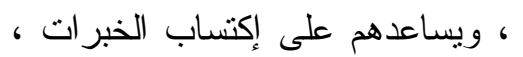
وتطوير المهار ات البحنية، وتشاركى البنى

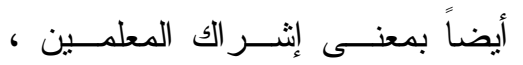
و المشرفين ، او هيئات خارجية بشكل بـن تعاونى . تصن أدوات بحوث العمل : 
الممارسون بهدف حل المشكلات، وتحسـين الممارسة، أو تعزيز الفهم، ويكــون عـادةً

تعاونى • (Nunan, 1992, 229)

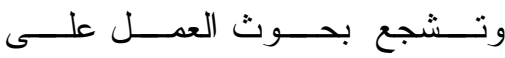

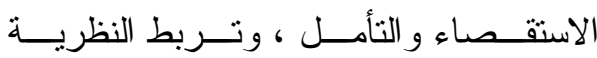
بالممارسة ، و تخلق رو ابط بين التدريس قبل ولبط و أثتـــاء الخدمسـة ) Kitchen \& Stevens, 2008, 7 بالخيار ات، ومن خلال الاستة صـاء يمكـن رؤية وشرح تللك الخيار ات، ويكمن مفتــاح

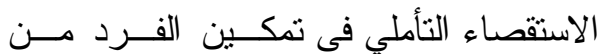
إدر الك خيار اته و النتـــائج المتزتبــــة عليهـــا، و اتخاذ أفضل الخيــار ات الممكنـــة لمو اقفـــهـ الخاصة و هذا يستدعى طر ح الأسئلة المسبقة قبل وأثثاء وبعد اتخاذ أي إجر اءات من أجل

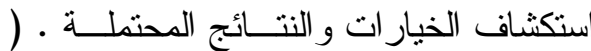

(Johnson et al, 2010, 61

ويتفق العديد من الباحثين أن عمليـــة البحث و الاستقصاء يمكن أن تغذى الممارسة

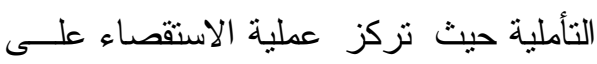

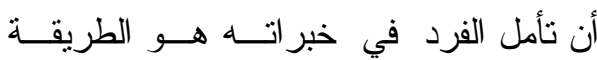
الوحيدة لتحسين تعليمه، ويـدور التـدريس لفريس حول عملية صنع القرار، ويجب أن يــــنبط ونيط صنع القرار ببعض الأيديولوجية العقلانيـــة القائمة على الأبحاث ، و إذا شارك المعلمون

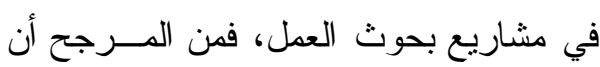

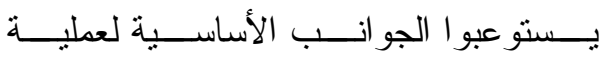

إلــــى زيـــادة الكفـــاءة المهنيـــة للمعلمــين.

(Capobianco et al, 2004)

وقد توصلت در اسة (Halim et al,

(2010 أن بحث العمل طور وعزز جوانب مختلفة من النطوير المهني للمعلم الطالــب، كما ساعد فى حل المشكلات فــى تــدريس الفيزياء التى واجهت الطلاب كما توصـلت لته در اسة (Vaino, 2013) إلى فعالية بحــوث العمل فى تغيير معتقدات المعلمـين الــليبية

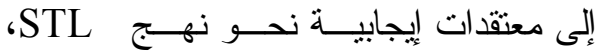
وشجعهم على تتفيذ ممارسات تعليمية جديدة، كما أظهرت أن استجابات الطلاب نحو هــــا النهج أعلى بكثير مقارنة بــدروس الكيميــاء السابقة .

المحور الثالث: العلاقـة بـين الاستقـصائ التـأملى

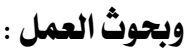
الاستقصاء هو مجموعة من العمليات العقلية أو الحسحركية يتم اتباعها لإيجاد حل هل هل لمشكلة ما، وتتضمن الملاحظة، و التصنيف،

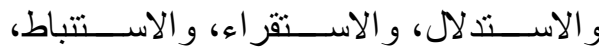

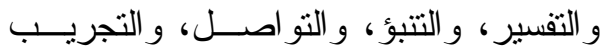

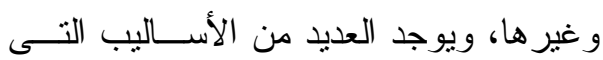

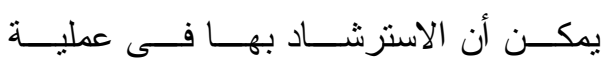

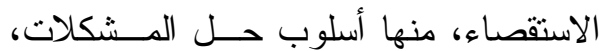

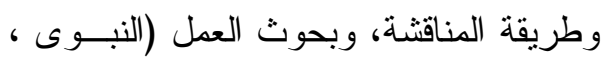

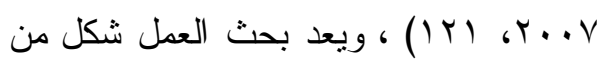

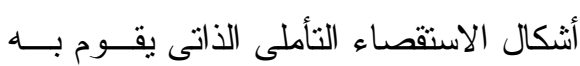


الإطلاع على البحوث و الدراســات الــسابقة

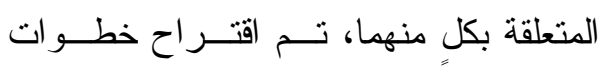

للاستقصـاء التأملى القائم على بحوث العدــــل على النحو التالى :

المرحلة الأولى : تحديد المـشكلة وجمـع

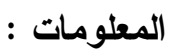

- يتم وضع التلاميذ فى موقف تعليمسى

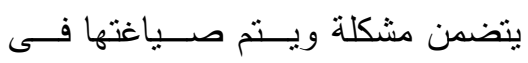
صورة سؤ ال .

- التعرف على الأفكار و المفاهيم السابقة

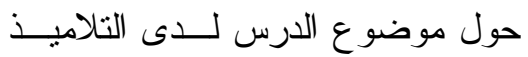
ووضع حلول مقترحة للمشكلة بصورة فردية .

المرحلة الثانية : الاستكثاف والتطبيق :

- تقسيم التلاميذ إلى مجموعات تعاونيــة صغيرة يتر اوح عددها ما بين (V-0) تلاميذ .

- يتناقش تلاميذ كـلـل مجموعــة فيمـــا توصلو ا إليه من حلول مقترحة للمشكلة

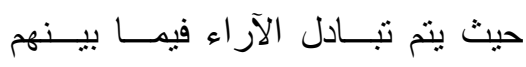

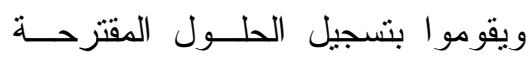

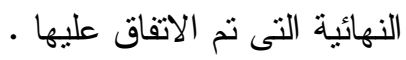
- ينفذ التلاميذ الأنـشطة الإستة صـائية

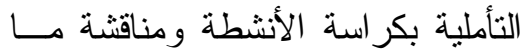

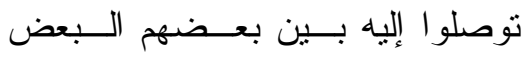

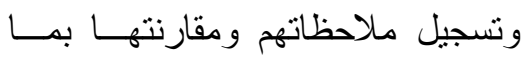

الاستقصاء و هى : صياغة الفروض، ومسح

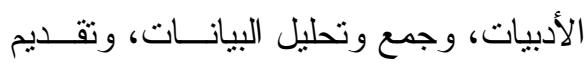

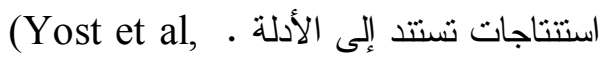
2000, 43-44) و هنالك الكثير مــن الدر اســات التـى

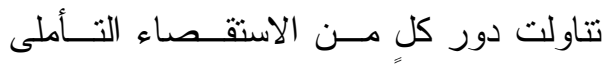

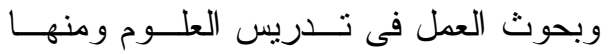
در اسة (Unlu et al, 2015) التى توصلت إلى فعالية التعلم القـائم علــى الاستقــصـاء

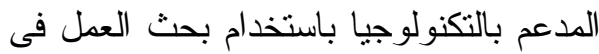

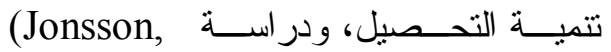
(2009 التى توصلت إلى أن تعلـــم العلـــوم ودئه القائم على الاستقصـاء باستخدام بحث العمـلـل

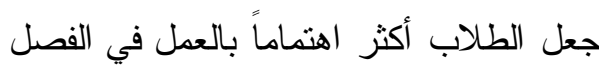
الدر اسى و أصبحو أكثر قيادة في مشاريعهم

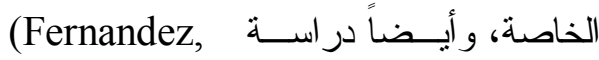
(2017 التى توصلت إلى أن الــتـعلم القـــائم

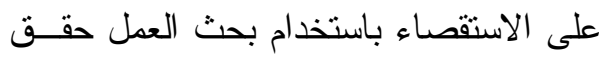
مكاسب كبيرة فى الفهم المفاهيمى و الفعاليــة

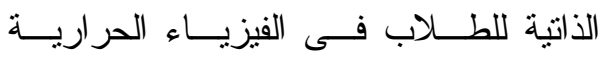
بالإضافة إلى وجود علاقـــة تبادليـــة بــين تحصيل الطلاب و الفهم المفاهيمى للموضوع

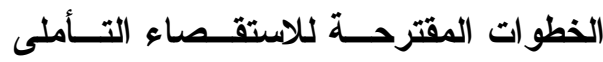
القائم على بحوث العمل : بناءً على خطوات الاستقصاء التأملى، ونماذج بحوث العمل السابق ذكرها، وبعـد 
كل ما يعرض عليه مــن معلومسـات وهــــا

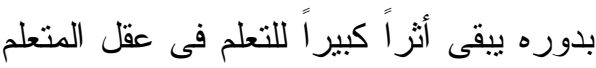

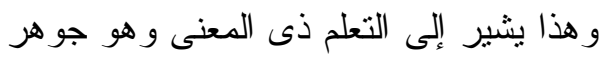
ما نركز عليه استر اتيجيات التدريس الحديثة

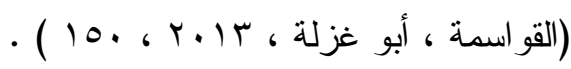
مفهوم التفكير التأملى : يمكن تعريف التفكير التأملى تعريفــاً

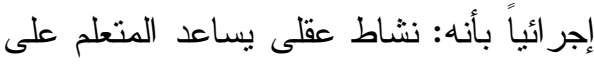

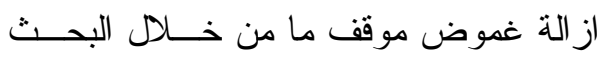

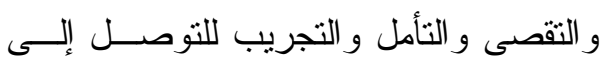
حقائق و استتناجات تمكنه من حل المشكلات ويقاس بالدرجة التى يحصل عليها التلميذ فى ونى

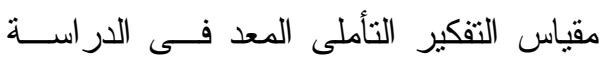

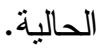
مهارات التفكير التأملى :

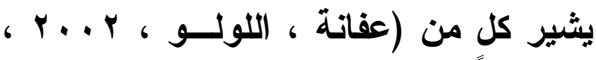

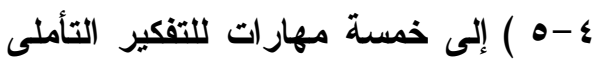

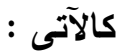
1- التأمل و الملاحظة : وتعني القدرة على

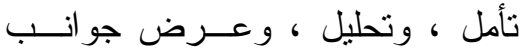
المشكلة ، و التعرف على محتو اها من

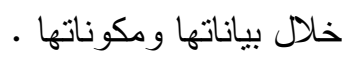
r- الكثف ع عن المغالطات: هيى القــدرة على توضيح الفجوات فى المشكلة؛ من خلال تحديد العلاقات غير الــصحيحة

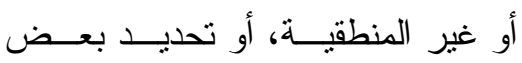

توصو ا إليه قبل تتفيذ الأنشطة لاستبعاد

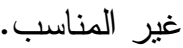
المرحلة الثالثة : التفسير و التأمل :

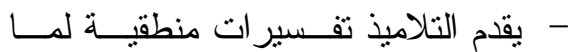
توصلو ا إليه بعد تتفيذ النشاط . - بجيب التناميذ على سؤ ال " ماذا لــــ " بعد كل نشاط يقوم الطلاب بتتفيذه ـ - يستمع المعلم إلى مـــا توصــل إليــــ التلاميذ من حلول للمشكلة مع تقــديم التعزيز المناسب . التعند المرحلة الر ابعة : التقويم : - تقديم بعض الأســئلة حــول المـشكلة

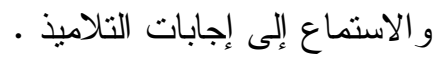
فى نهاية كل أسبوع يطلب المعلم من

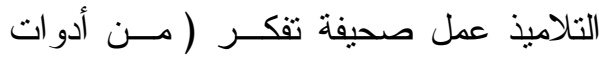
بحوث العمل ) لتسجيل أحداث ما قامو ا بــه

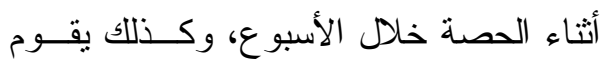
بعمل صحيفة التقكر الخاصة بــه وتـسجيل ممارساته أسبو عياً .

\section{المحور الرابع : التفكير التأملى وتدريس العلوم :}

يعد تتمية التفكير وخاصةً التأملى من أهداف تدريس العلوم وذلك على اعتبــار أن لن التفكير التأملى يجعل الطالب يخطـ طـ دائمـــاً

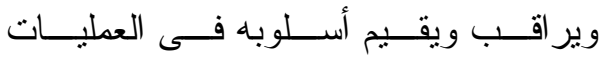
و الخطوات التى يتبعها لاتخاذ القرار ، ويقوم التفكير التأملى على تأمل وتمعن الطالب فى لبع لانى 
ومنها در اسة (البعلى، ج + . ب) التى توصلت

إلى فعالية وحدة مقترحة فى الفيزياء قائمسـة

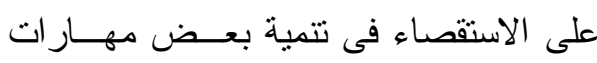

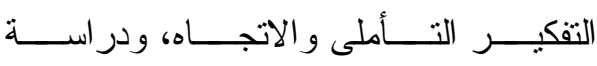

Murphy, 2014))

الممارسة التأملية فى تتمية التفكير التــأملى لتى

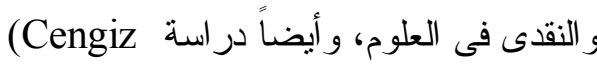

ف Karataş, 2015)

فعالية صحف التأمل و الأنـشطة المدعومـــة

بالتغذية الر اجعة فى تحسين تحصيل معلمـى

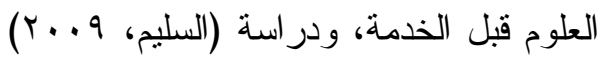

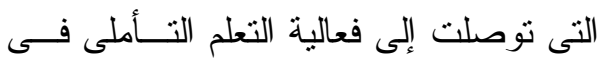

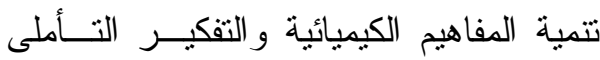

وتتظيم الذات للتعلم، بالإضـافة إلــى در اســــة

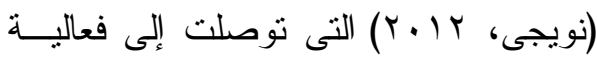

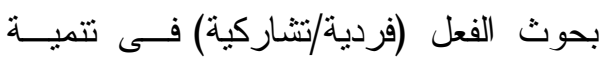

الأداء التدريسى ومستوى التفكير التأملى لدى

الطلاب المعلمين بشعب العلــوم، ودر اســـة

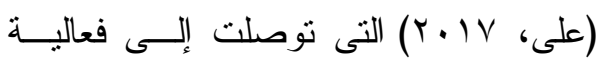

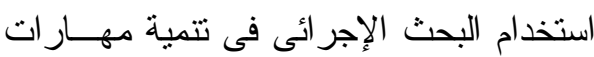

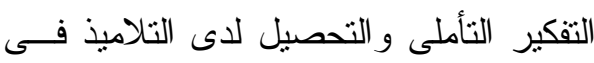

العلوم.

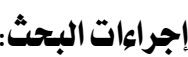

أولاء: إعداد مواد المعالجة التجريبية :

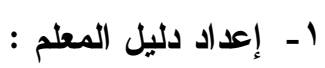

تم إعداد دليل المعلم بحيث يتـ ضمن

مقدمة توضح نبذة مختصرة عن الاستقصاء
الخطوات الخاطئة فى انجــاز المهــام

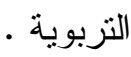

r- الوصول إلى استتناجات للمشكلة: وهى

القدرة على إيضاح العلاقـــة المنطقيـــة

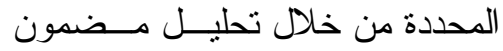

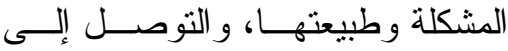

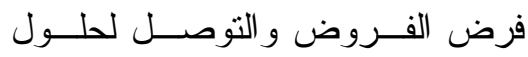
مناسبة .

ـ - إعطاء تقسير ات مقنعة: هــى القــدرة

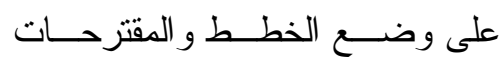

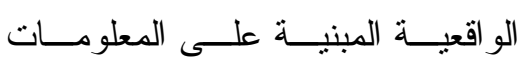

و المعرفة الصحيحة لحل المشكلة .

0- وضع حلول مقترحة : هى القدرة على

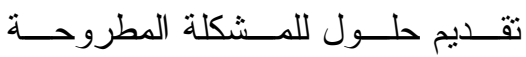

بخطو ات منطقية .

سوف تقتصر الدراسة الحالية علـى في

بعض مهار ات التقكير التأملى وهى : التأمل

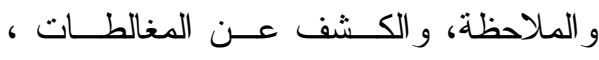

و التوصل إلى استنتاجات صحيحة، و إعطــاء

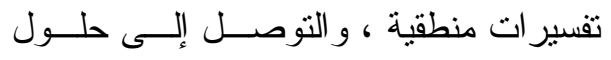

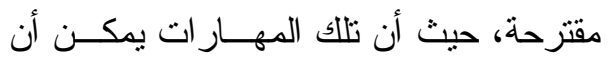

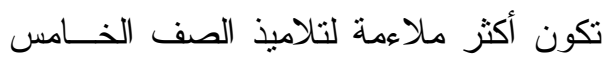

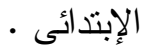

و هنالك بعض الدر اسات التى نتاولـــت

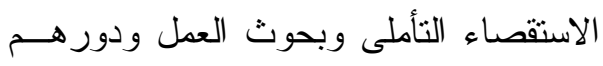

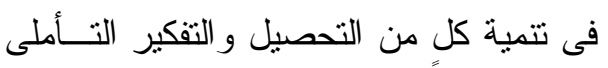


أ) تحدبد الههف من الاختبار: هـدف

الاختبار قياس مسـستوى تحـصيل

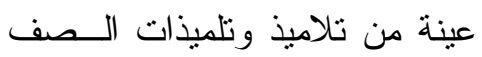

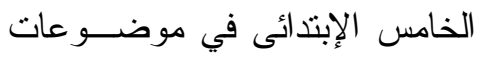

وحدة "الجهاز الــدورى و الجهــاز الإخر اجى" من مادة العلوم.

ب) إعداد قائمة بالأهداف التي يقيسها

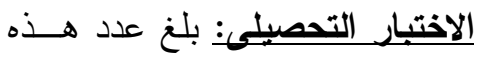
الأهداف (• ع) هدفاً سلوكياً.

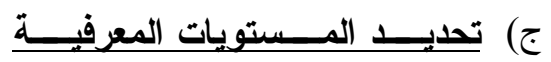
المتضمنة في الاختبار التحصيلى:

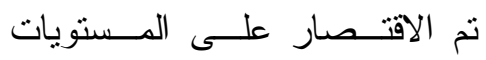

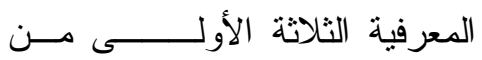

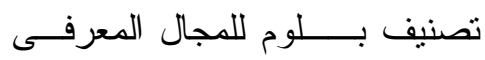
وهى (التذكر ، و الفهم، و التطبيق). د) إعداد جدول المواصفات : تم تقسيم وحدة " الجهاز الــدورى و الجهــاز

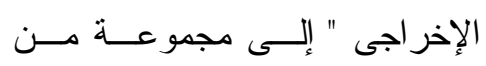

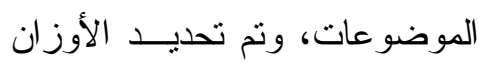
النسبية لموضو عات الوحدة، وكذلك

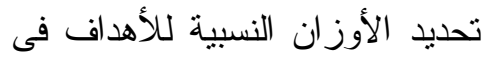
المستويات المعرفية الثلاثة (التذكر

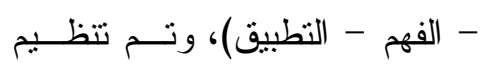
البيانات التي تم الحصول عليها كما يوضحه الجدول (1) الثالى:
التأملى القائم على بحوث العهـلـ، وكيفيــة

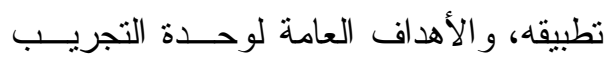

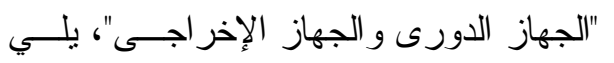
ذللك تخطيط لتدريس دروس الوحدة والخطة الزمنية في وحدة " الجهاز الدورى و الجهــاز

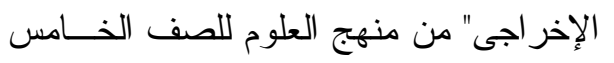

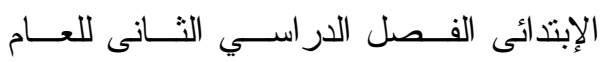

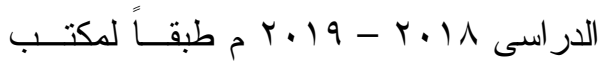
تتمية العلوم التابع لوزارة التربية و التعلــيم. وتم عرض دليل المعلم على مجموعة مــن

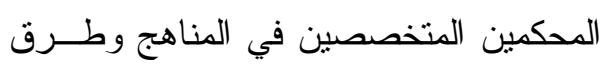

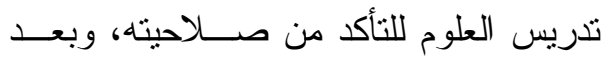

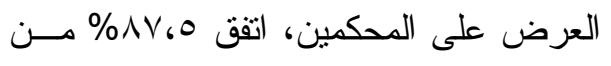
المحكمين على صلاحية استخدام دليل المعلم.

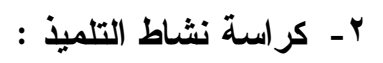
تم إعداد كر اسة نشاط التلميــــ حيـــث تتضمن العديد من الأنـشطة الاستقـــلئية

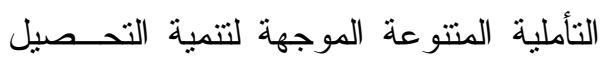

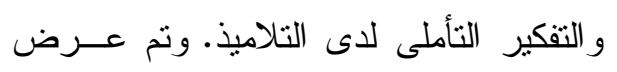
كر اسة النشاط على المحكمين المتخصــصين

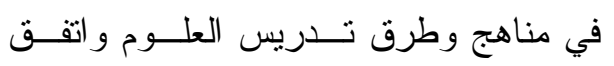

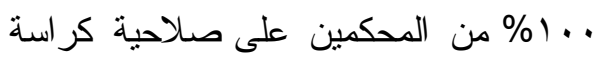

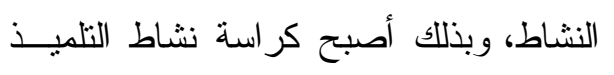
جاهزة في صورنها النهائية.

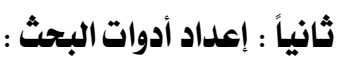
(1) إعداد الاختبار التحصيلي: نم إعداد ادوات

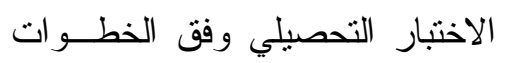
التالية: 


\section{جدول (1)}

جدول مواصفات الاختبار التحصيلي لوحدة "الجهاز الدورى والجهاز الإخراجى"

\begin{tabular}{|c|c|c|c|c|c|}
\hline للموضوعات النسبى & الأسئلة & 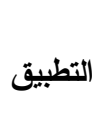 & 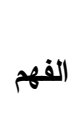 & 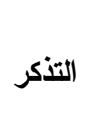 & مستويات للأهلاف \\
\hline$\% \circ$. & $r \cdot$ & r & 1. & $v$ & 1- الجهاز الدورى و الدور ان فى الإنسان \\
\hline \multirow[t]{2}{*}{$\% \circ$. } & $r \cdot$ & $r$ & 1. & v & r- الإخر اج فى الإنسان \\
\hline & $\varepsilon$. & 7 & $r$. & $1 \leqslant$ & مجموع الأسئلة \\
\hline$\%, \ldots$ & & $\%$ & $\% \circ \varepsilon$ & $\%$ \%rr & الوزن النسبى للأهداف \\
\hline
\end{tabular}

المتخصصين في منــاهج وطــرق تـــريس \%) تحدبد نــوع مفـردات الاختبــار

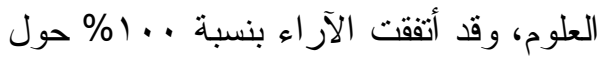
وصباغة تعليماته:تنم صياغة أسئلة

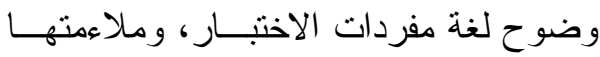

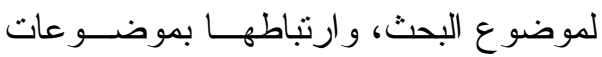
الاختبار من نوع أسئلة الاختيار من صنياع

$$
\text { الوحدة و أهد افها. }
$$

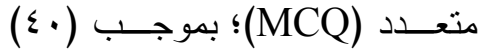

r- التجربة الاستطلاعية للاختبار مفردة، لكل سؤ ال (ع) بدائل يوجد

\section{التحصيلي وإجر اءات تطبيقها:}

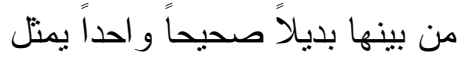

تم إجراء التجربة الاستطلاعية الإجابة الصحيحة علــى الـسؤ ال،

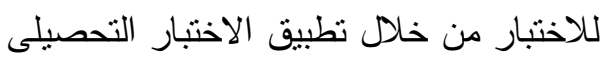
وتم صياغة تعليمات الاختبار بلغة تتسم بالوضوح ليتمكن التلميذ مـن في صورته المبئية على عينة من تلاميذ الصف الخامس الإبندائى - غير عينة البحث الأساسية - بمدرسة الثهيد جمال فائق الإبندائية التابعة لإدارة أجا التعليمية، وقد بلغ بلغ التهايه عددها (·r) تلميذاً وتلميذة، وتم تصحيح الاختبار ورصد الدرجات لكل تلميذ وتلميذة ونمات

$$
\text { وذلك للتوصل إلى الآتى: }
$$

أ - تحديد الزمن اللازم للإجابــة علـى الاختبار التحصيلى: تم حساب الزمن لزئل

$$
\begin{aligned}
& \text { و) تجريب الاختبار وضــبطه علمبـ } \\
& \text { (المحدات السيكومترية) وتتضمن } \\
& \text { 1-تحديد صدق محتوى الاختبار: } \\
& \text { (صدق المحكمين) } \\
& \text { تم عرض الصورة الأولية للاختبـــار }
\end{aligned}
$$

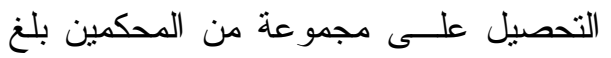

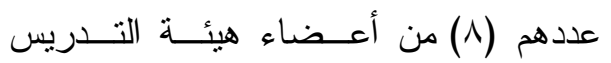


الاختبار التحصيلى جاء معامل التمييز في المدى المقبول من (ع، . - ه، •) . ه- حساب الالــساق الـــاخلي للاختبــار التحصيلي : تم حساب صدق الاتساق

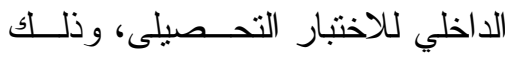
من خلال حساب معامل ارتباط درجة

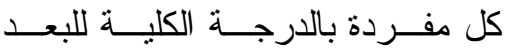

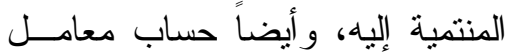
ارتباط درجة كل بعـــ مسن أبعـاد البهاد

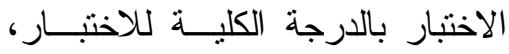
و اتضح أن معاملات الارنباط موجبة وذات دلالة إحصائية عنــد مسستوى

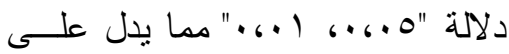
صدق الاتـساق الــــاخلي للاختبـــار

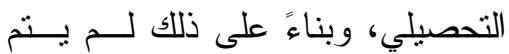

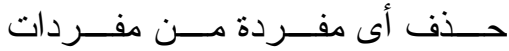
الاختبار، وبــنلك يكــون الاختبـار التحصيلى فى صورنه النهائية مكوناً

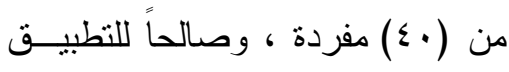

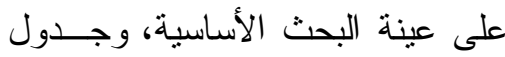

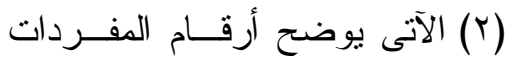
موزعة على المـستويات المعرفيــة

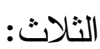

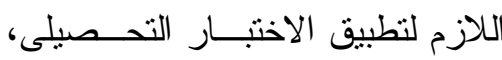

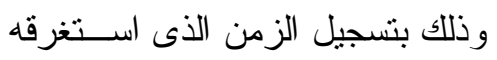
كل طالب من العينة الاستطلاعية في

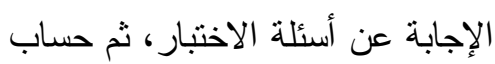

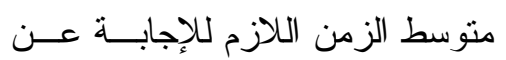

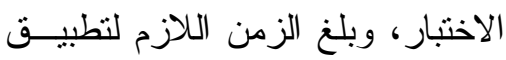

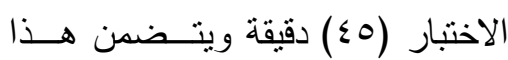
الزمن زمن إلقاء تعليمات الاختبار . ب - حسـساب معامـلـل ثبــات الاختبـــار التحصيلى: نم استخدام طريقــة ألفــــا كرونباخ في حساب معامـل ثبــات الاختبار التحصيلى و اتضح أن قيمــة الثبات (10)،.، مما بدل على ملاعمة الاختبار لأغر اض البحث.

ج- حساب معاملات السهولة والصعوبة لمفردات الاختبار التحصيلى: بحساب معامل الـسـهولة لكــل مفــردة مــن

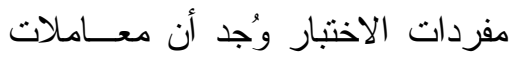

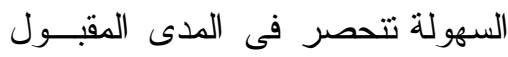
بين (r، • - ^^، •). دـ - حساب معساملات التميــز لمفــردات الاختبار التحصيلى: بحساب معامـلـ لــل التمبيز لكل مفـردة مــن مفــردات 


\section{جدول (ץ)}

أرقام الأسئلة موزعة على المستويات المعرفية

التي يتضمنها الاختبار التحصيلي في صورته النهائية

\begin{tabular}{|c|c|c|}
\hline 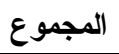 & أرقام الأسئلة & المستويات المعرفية \\
\hline ir & $r 96 r q, r \Lambda, r \cdot 61961761 r_{6}, 1606 \leq 6 r 61$ & 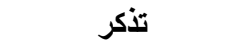 \\
\hline rr & 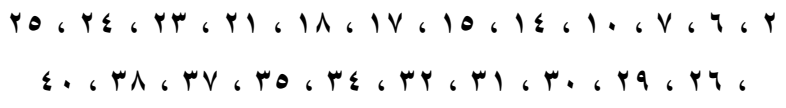 & فهم \\
\hline 7 & $r r$ ، rV، rr, $6 r$ ، 1169 & تطبيق \\
\hline
\end{tabular}

r - إعـــداد قائمــة مهــــارات التفكبـر

التأملى: بعد الاطلاع على الأبحاث

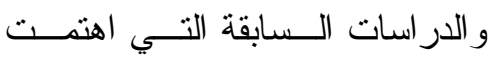
بتتمية مهار ات التفكير التأملى ، تـــ

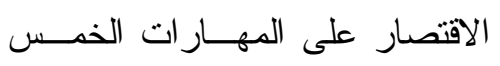

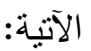

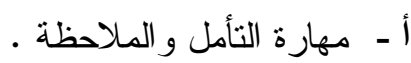
ب - مهارة الكثف عن المغالطات . ج - مهارة التوصل إلى اســتنتاجات

$$
\text { منطقية - مثارة }
$$

د - مهارة إعطاء تقسبرات مقنعة . هـ - مهـــارة التوصــل إلــى حلــول مقترحة . مقة المغ r- صباغة عبارات المقيّاس وتعليماته:

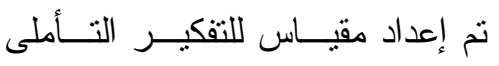
وتكون فى صورته الأولية من (r (Y)

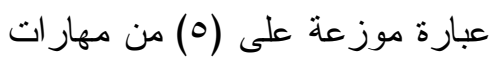

\section{ز) مفتاح تصحيح الاختبار:}

بعد الانتهاء من إعداد الاختبــار فـى لـى

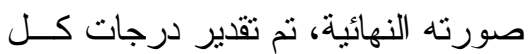

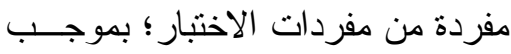
درجة واحدة فى حالة تطــابق إجابــة فئة التلميذ علــى الـسؤ ال مـــع الإجابــة

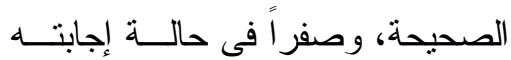
إجابة خاطئة، وبلغت الدرجة النهائيـــة

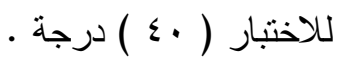

(ץ) إعداد مقياس التفكير التأملى :

1 - تحدب الهيف من المقياس: استهدف

مقياس التفكير التأملى قيــاس قــدرة تلاميذ وتلميذات الــصف الخــامس الإبتدائى على ممارسة مجموعة من

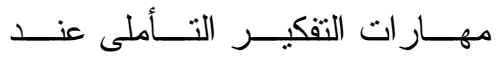

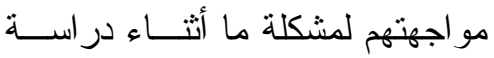
· العلوم 
تم تطبيق المقياس فى صورته الأولية

التفكير التأملى المحددة سلفاً، وتــتم

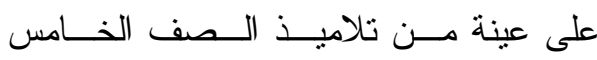

الاستجابة على كل منها وفقاً لتندرج

الإبتدائى - غير عينة البحــث الأساســية -

ثلاثى البدائل كالتالى (دائماً ، أحياناً

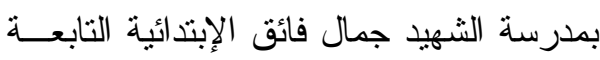

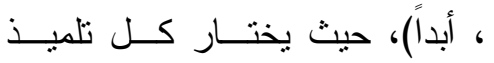

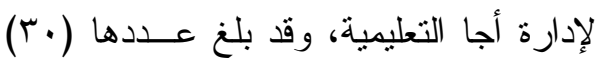

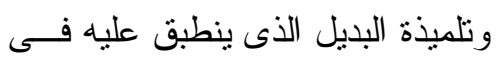

تلميذاً وتلميذة، وتم تصحيح المقياس، ورصد

كل عبارة، كما تم صياغة تعليمـات

درجات كل تلميذ وتلميذة للتوصل إلى الآتى

المقياس بلغة تتسم بالوضوح حليتمكن

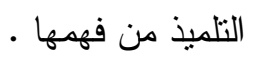

أ - تحديد الزمن الــلازم للإجابــة علـى

צ- تجريب المقياس وضـبطه علمبـاً

(المحدات السيكومترية) وتتضمن : :

تم حساب الزمن اللازم للإجابة على تلى

(أ) تحديـــــ صــــق المقيـــاس: (صــــق

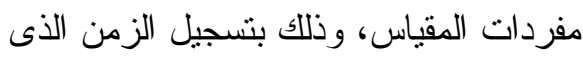

(المحكمين)

استغرقه أول طالب من العينة الاســنطلاعية

تم عرض الصورة الأولية للمقيــاس

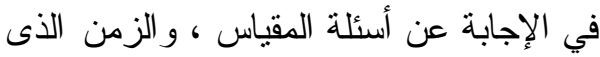

استغرقه آخر طالب فى الإجابة عن أســئلة

على عدد (^) من المحكمين المتخصــصين

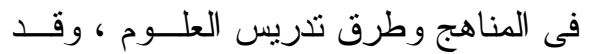

المقياس، ثم حساب متوسط الــزمن الــلـازم

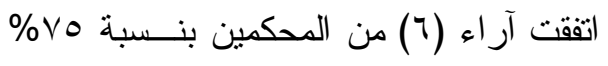

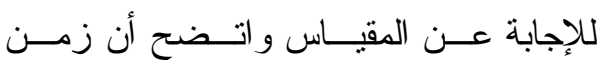

المقياس بلغ (·r) دقيقة ويتضمن هذا الزمن

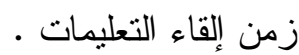

ب - حساب معامل ثبات اختبار طبيعة العلم

حول ملاعمة عبار اته من الناحية العلميــة ،

و ارتباطها بمادة العلوم ومناسـبتها لأنـشطة

الوحدة ، و أثثار البعض إلى عــدم مناســـبة

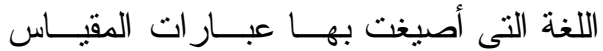

لتلاميذ الصف الخامس الإبتدائى، لـــللك تــــ

تم حساب ثنات المقيـــس باســتخدام

إعادة صياغة تلك العبار ات، وبذللك أصــبح

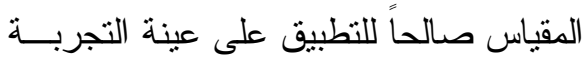

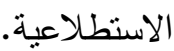

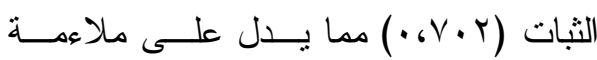

المقياس لأغر اض البحث الحالى.

(ب) التجربة الاستطلاعية لمقياس التفكير

ج-حساب الاتساق الاخلي:

التأملى وإجر اءات تطبيقه: 


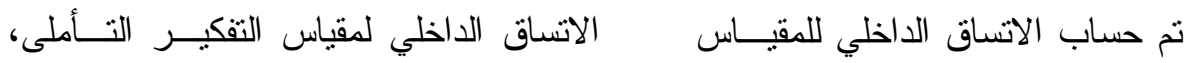

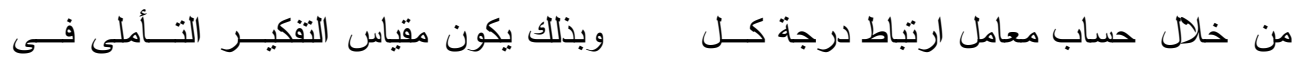

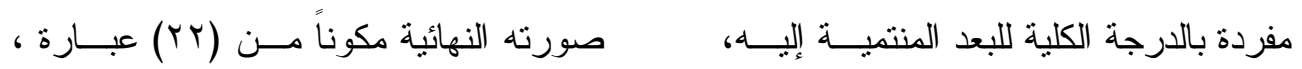

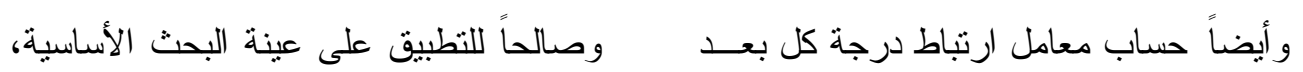

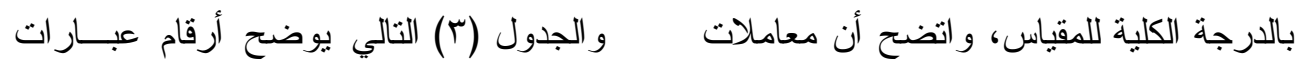

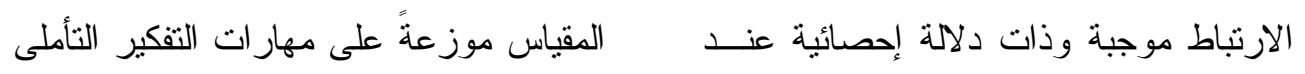

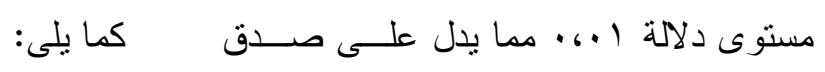

جدول (r)

أرقام العبارات موزعة على المهار ات التي يتضمنها مقياس

التفكير التأملى في صورته النهائية

\begin{tabular}{|c|c|c|}
\hline 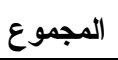 & أرقام العبارات & مهارات التفكير التأملى \\
\hline 1 & 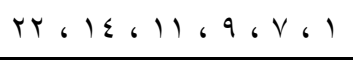 & ا - التأمل و الملاحظة \\
\hline 。 & YI. 19, IV, Ir, O & r- الكثنف عن المغالطات \\
\hline 0 & $17 ، 1 \pi ، 7 ، \varepsilon$ ، & r- التوصل إلى استتاجات صحيحة \\
\hline r & $1 \wedge ، \wedge ، r$ & ك- إعطاء تفسير ات مقنعة \\
\hline r & $r \cdot .10 ، 1$. & هـ النوصل إلى حلول مقترحة \\
\hline rr & & ل ب ل ع الكلى \\
\hline
\end{tabular}

درجة واحدة فى حالة اختياره للبديل

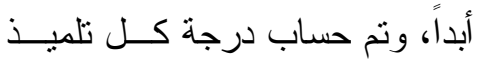

التأملى :بعد الانتهاء مسـن إعــداد

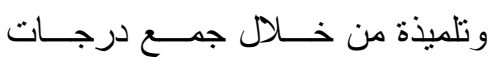

المقياس فى صورته النهائية ، حيث

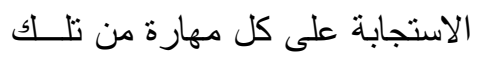

كانت بدائل الإجابة علــى المقيـــاس

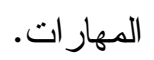

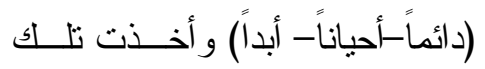

: (r)

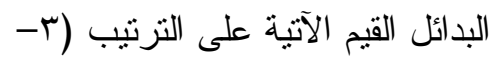

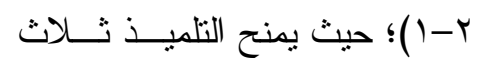

تم استخدام صحيفة التفكر لكل مــن

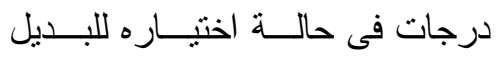

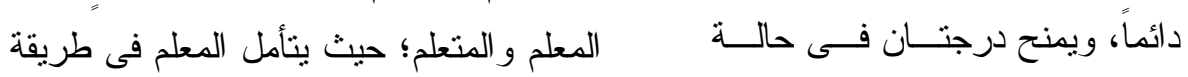


تدريسه التى بتبعها وهى الاستقصاء التأملى رابعاً : عينة البحث:

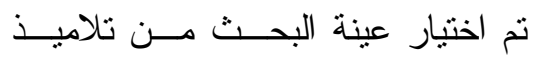

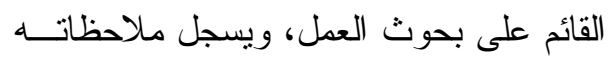

الصف الخامس الإبتدائى بمدرستي الـشهيد

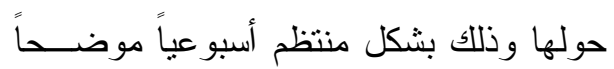

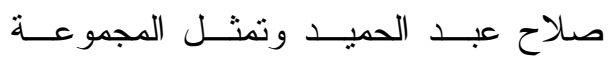

الأخطاء النى وقع بها لتجنبها، ومدى تحسنه

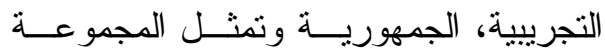

أثناء فترة التدريس، ومردود طريقة التدريس بهاه الضابطة وفقاً للجدول (ع ) الآتى:

المتبعة على تلاميذه، ورصد لحظات الإحباط

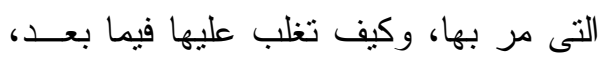

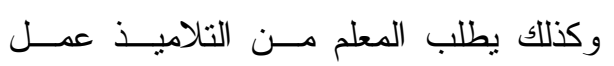
صحيفة تفكر خاصة بكل تلميذ يسجل فيهـا الأحداث التى يقوم بها داخل الفصل، ويتأمل

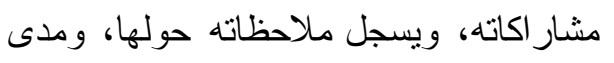
تحسنه على مدار الحصص. ثالثاً : منهج البحث و متغيراته :

التطبيق القبلى لأدوات البحث : تم التطبيــق القبلــى لأدوات البحـــث

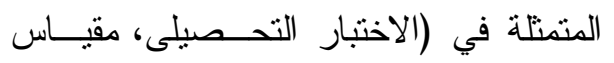

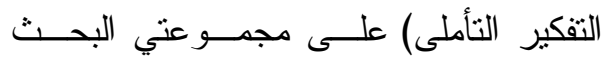

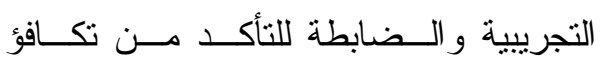

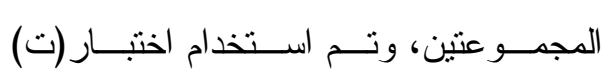
المتغير المـستقل: طريقــة التــريس

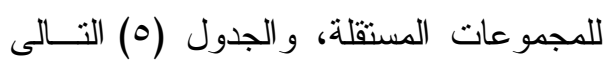

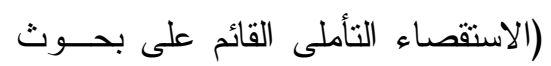

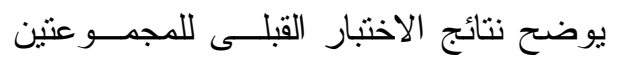

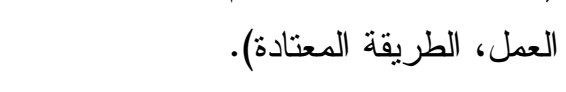
التجريبية و الضابطة:

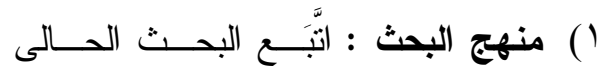

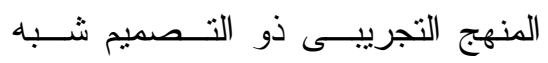
التجريبى. ( ) متغير ات البحث : (r) المتغير ات التابعة: التحصيل، و التفكيــر

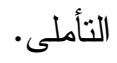




\section{جدول (0)}

قيمة (ت) ودلالتها الإحصائية للفروق بين متوسطي المجموعتين التجريبية والضابطة في جلول

القياس القبلي للاختبار التحصيلى منوسيطي

\begin{tabular}{|c|c|c|c|c|c|c|c|}
\hline مستوى & الدرجية & قيمة (ت) & الالمراف & المتوسط & ن & المجموعة & أبعاد الاختبار \\
\hline \multirow{2}{*}{ غير دالة } & \multirow{2}{*}{19} & \multirow{2}{*}{ ו } & אחד. 1 & ¿،八 & $\varepsilon V$ & التجريبية & \multirow{2}{*}{ التذكر } \\
\hline & & & $1.7 \mathrm{KA}$ & $0, .0$ & $\varepsilon \varepsilon$ & الضابطة & \\
\hline \multirow{2}{*}{ غير دالة } & \multirow{2}{*}{19} & \multirow{2}{*}{1,511} & $1,7 \ldots$ & $v_{6} v$. & $\leqslant V$ & التجريبية & \multirow{2}{*}{ الفهم } \\
\hline & & & $1,90 \leqslant$ & V.ro & $\leqslant \varepsilon$ & الضابطة & \\
\hline \multirow{2}{*}{ غير دالة } & \multirow{2}{*}{19} & \multirow{2}{*}{1.799} & . 6107 & 1.01 & $\varepsilon V$ & التجريبية & \multirow{2}{*}{ التطبيق } \\
\hline & & & $1,1 \% 0$ & 1,199 & $\leqslant \varepsilon$ & الضابطة & \\
\hline \multirow{2}{*}{ غير دالة } & \multirow{2}{*}{19} & \multirow{2}{*}{.64 .9} & r.VA9 & $1 \varepsilon_{6} . \varepsilon$ & $\varepsilon v$ & التجريبية & \multirow{2}{*}{ الدرجة الكلية } \\
\hline & & & rotorr & $1 \leq 611$ & $\varepsilon \varepsilon$ & الضابطة & \\
\hline
\end{tabular}

ويوضح الجدول (T) التالى نتائج اختبار (ت) قبلياً للمجموعـات المــنقلة للمجـــوعتين

التجريبية و الضابطة وذلك للتأكد من تكافؤهما في مقياس التفكير التأملى :

جدول (†)

نتائج اختبار (ت) لالالة الفروق بين متوسطي المجموعتين التجريبية والضابطة في القياس

\begin{tabular}{|c|c|c|c|c|c|c|c|c|}
\hline مستوى & الحرية & قلتيمة (ف) & قيمة & الاحعراف & المتوسط & ن & المجموعة & مهارات التفكير \\
\hline \multirow{2}{*}{ 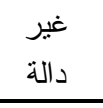 } & \multirow{2}{*}{19} & \multirow{2}{*}{$r, Y ৭ 4$} & \multirow{2}{*}{$1,1 \leqslant r$} & r.rV & $\Lambda_{G}, r \mu$ & $\leqslant V$ & التجرييية & \multirow{2}{*}{ مهارة التأمل } \\
\hline & & & & $1, \varepsilon \cdot V$ & $\lambda_{6} V$ & $\varepsilon \varepsilon$ & الضابطة & \\
\hline \multirow{2}{*}{ 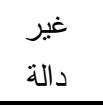 } & \multirow{2}{*}{19} & \multirow{2}{*}{$\cdot, \cdot 9 \leq$} & \multirow{2}{*}{$1, \leqslant 79$} & $1.91 \%$ & VGrr & $\leq V$ & التجرييية & \multirow{2}{*}{ مهارة الكشف عن } \\
\hline & & & & $1, V Y$ & $V_{6} \wedge$ & $\varepsilon \varepsilon$ & الضابطة & \\
\hline \multirow{2}{*}{ 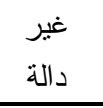 } & \multirow{2}{*}{19} & \multirow{2}{*}{ - ro } & \multirow{2}{*}{$\cdot$ • $\vee \wedge \varepsilon$} & 1.20 & $V_{6} r 4$ & $\leq V$ & التجرييية & \multirow{2}{*}{ مهارة التوصل إلى } \\
\hline & & & & 1.ATV & V.77 & $\varepsilon \varepsilon$ & الضابطة & \\
\hline \multirow{2}{*}{ غ غالة } & \multirow{2}{*}{19} & \multirow{2}{*}{$\cdot, 7)$} & \multirow{2}{*}{$1, \varepsilon r$} & $1 . .07$ & $\varepsilon$ « & $\leqslant v$ & التجرييية & \multirow{2}{*}{ تفسيرات مقتعة } \\
\hline & & & & $.690 \leqslant$ & $\varepsilon, V$ & $\leq \varepsilon$ & الضابطة & \\
\hline \multirow{2}{*}{ غير } & \multirow{2}{*}{19} & \multirow{2}{*}{ r.10r } & \multirow{2}{*}{. 104} & $1,7 . r$ & $\{.71$ & $\varepsilon V$ & التجرييية & \multirow{2}{*}{ مهارة التوصل إلى } \\
\hline & & & & I.TAT & $\varepsilon_{\text {QV }}$ & $\varepsilon \varepsilon$ & الضابطة & \\
\hline \multirow{2}{*}{ 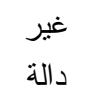 } & \multirow{2}{*}{19} & \multirow{2}{*}{ } & \multirow{2}{*}{1.799} & $0, \wedge 10$ & $r 1.91$ & $\leq V$ & التجرييية & \multirow{2}{*}{ اللارجة الكلية } \\
\hline & & & & r.74 & Tr.tT & $\varepsilon \varepsilon$ & الضابطة & \\
\hline
\end{tabular}


متغيــر ات البحـــث (التحــصيل - التفكيــر

التأملى)؛ وذلك لإجر اء المعالجة الاحــــائية

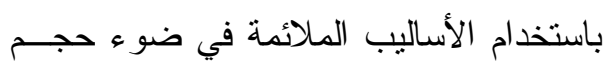
العينة وطبيعة المتغير ات.

نتائج البحث:

أولاً: النتائج المتعلقة بالسؤال الأول:

للإجابة عن السؤال الأول الذي نــص

على"ما فعالية الاستقصاء التأملى القائم علــى لإنى بحوث العمل فى تتمية التحصيل لاى تلاميذ المرحلة الإبتدائية؟"، تم اختبار الفرض لهنه الأول من فروض البحث، الذى نص علــى"توجــــ فروق ذات دلالة إحصائية عند مستوى دلالة

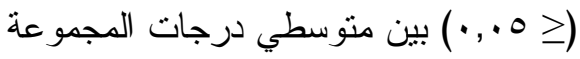
التجريبية و المجموعة الضابطة في النطبيــق بـن البعدى للاختبار التحصيلي لصالح المجموعة ولئه

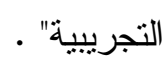

لاختبار هذا الفـرض تــم اســتخدام

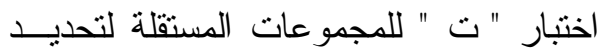
دلالـــة الفـروق بــين منوســـي درجــات

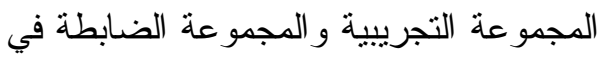
التطبيق البعدي للاختبار التحصيلى، ويتضح ذلك من خلا جدول (V) التالي :
يتــــــــن الجــدولين (0) و (7) السابقين أن قيم " ت" غير دالة إحصائيًا عند

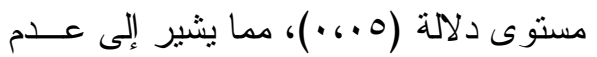

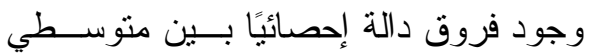
درجات المجموعنين التجريبية و الضابطة في الاختبار التحصيلي ومقياس مهار ات التفكير التأملي، وهذا يشير إلى تكافؤ المجمـــوعتين

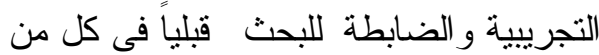
التحصيل و التقكير التأملى .

التذريس للمجموعتين التجريبية و الضابطة

تــم تــدريس المجموعــة الــضابطة

بمدرسة الجمهورية وحدة " الجهاز الــدورى و الجهاز الإخر اجى " بالطريقة المعتادة، بينما

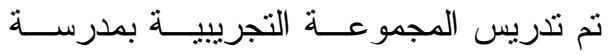

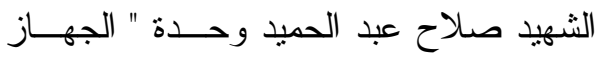
الدورى و الجهاز الإخر اجى" وفقاً للاستقصاء

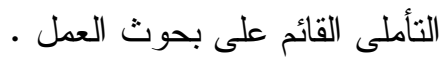
التطبيق البعدي لأدوات البحث:

بعد الانتهاء مــن تــدريس الوحـدة للمجموعنين التجرييية و الضابطة تم تطبيــق أدو ات البحث بعدياً على مجموعتي البحــث

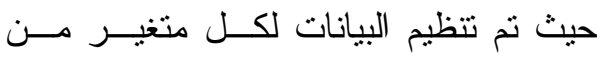




\section{جدول (v)}

قيمة (ت) ودلالتها الإحصائية للفروق بين متوسطي المجموعتين التجريبية والضابطة

\begin{tabular}{|c|c|c|c|c|c|c|c|}
\hline \multicolumn{8}{|c|}{ في القياس البعدي للاختبار التحصيلى } \\
\hline مستوى & الحرية & قيمة & المعياري & المتوسط & ن & المجموعة & أبعاد الاختبار \\
\hline \multirow{2}{*}{$\cdot 6 \cdot 1$} & \multirow{2}{*}{19} & \multirow{2}{*}{ Tr. } & .6919 & $11,9 \leq$ & $\leqslant v$ & التجرييية & \multirow{2}{*}{ التذكر } \\
\hline & & & 1.019 & $\Lambda_{\text {( }} \varepsilon 1$ & $\varepsilon \varepsilon$ & الضابطة & \\
\hline \multirow{2}{*}{$\cdot 6 \cdot 1$} & \multirow{2}{*}{19} & \multirow{2}{*}{$r V_{6} .7 T$} & I.r & $11_{6} \mathrm{rT}$ & $\leqslant V$ & التجريبية & \multirow{2}{*}{ الفهم } \\
\hline & & & $1 ، \leqslant 17$ & 1.60 & $\varepsilon \varepsilon$ & الضابطة & \\
\hline \multirow{2}{*}{$\cdot 6+1$} & \multirow{2}{*}{19} & \multirow{2}{*}{17.874} & $.0 \mathrm{r}$ & $0 . \mathrm{VV}$ & $\leqslant v$ & التجرييية & \multirow{2}{*}{ التطبيق } \\
\hline & & & .6900 & r.) & $\varepsilon \varepsilon$ & الضابطة & \\
\hline \multirow{2}{*}{.6 .1} & \multirow{2}{*}{19} & \multirow{2}{*}{$\leqslant 0, \wedge \wedge 0$} & $1, r \times 1$ & $r 0,19$ & $\leqslant v$ & التجرييية & \multirow{2}{*}{ الارجة الكلية } \\
\hline & & & 1,507 & rtr & $\varepsilon \varepsilon$ & الضابطة & \\
\hline
\end{tabular}

حجم التاثير لاستخدام الاستقصاي التأملى القـائم

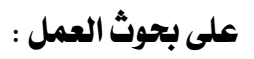

يتضح من الجدول السابق أن جميـع

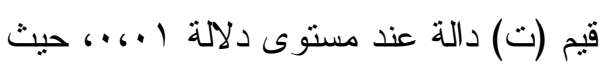

للتعرف على حجم التأثنر للاستقصاء

التأملى القائم على بحوث العمل فـــي تتميـــة

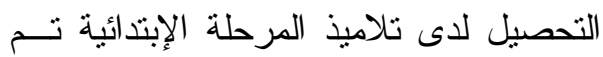

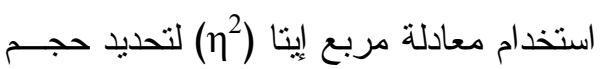

التأثنير • وذلك وفقاً للجدول (^) الآتى:

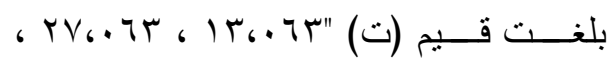

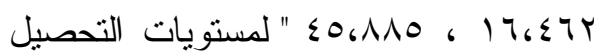

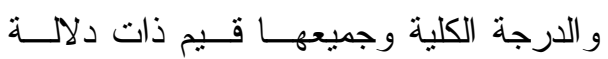

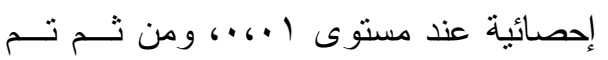

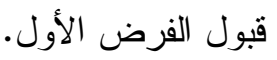

جدول (^)

حجم تأثير الاستقصاء التأملي القائم على بحوث العمل فى تنمية التحصيل فى مادة العلوم لاى

تلاميذ المرحلة الابتدائية

\begin{tabular}{|c|c|c|c|}
\hline حجم التأثير & قيمة (2 ) ) & قيم (ت) & أبعاد الاختبار التحصيلي \\
\hline 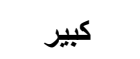 & $.694 \wedge$ & 14..74 & التذكر \\
\hline كبير ل & . 6974 & $r V_{6} .7 T$ & القهم \\
\hline 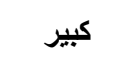 & $. ~ .9 \leqslant 9$ & 17، & التطبيق \\
\hline 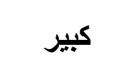 & .691 & $\leqslant 0, \wedge \wedge \theta$ & الارجة الكلية للتحصيل \\
\hline
\end{tabular}

YI. 
عليهم المعلم و هذا يؤدى إلى نسيانها ســريعاً

وصعوبة تذكر ها .

كما أناح الاستقصاء التــأملى القـائم

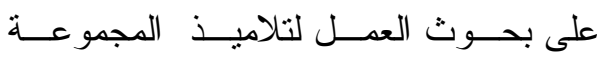

التجريبية الفرصة للمناقـشة الفعالــة بــين

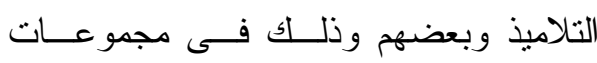

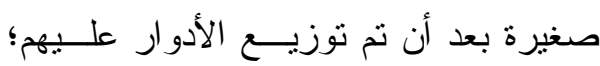

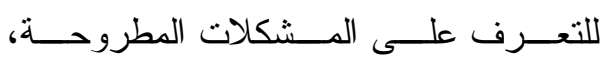

و المعلومات المتاحة حولها، و التعــاون معــاً

لتقديم أفضل الحلول لها من خـــلال تبــادل

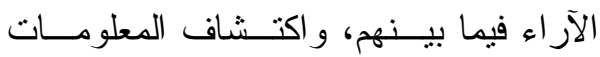

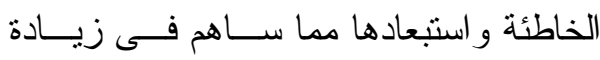

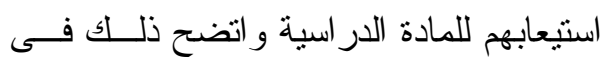

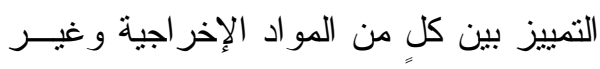

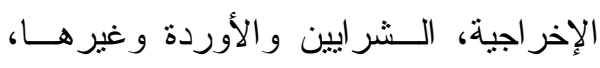

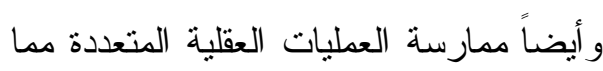

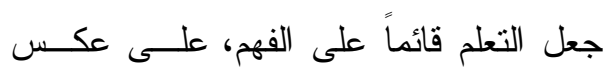

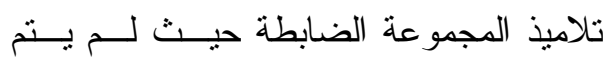

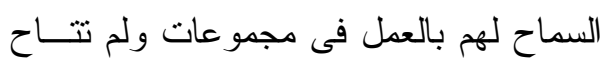

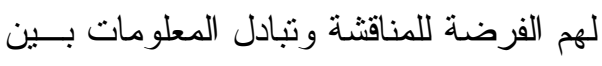
بعضهم البعض مما أدى لتندى مستوى الفهم

$$
\text { لديهم }
$$

وسمح الاستقصاء التأملى القائم علـى لـى

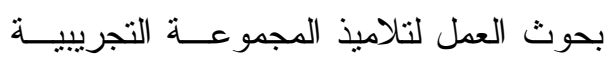
بيناء المعرفة بأنفسهم، و التوصل إلى الحقائق بأنفسهم بدلاً من تقديمها جاهزة إليهم من قبل ولفيل

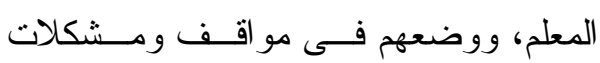

يتضح من الجدول السابق أن جميـع

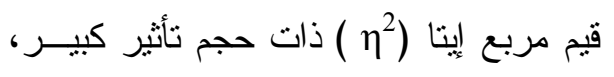

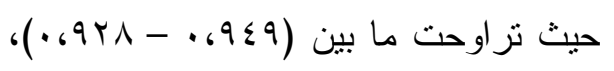

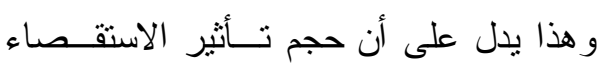

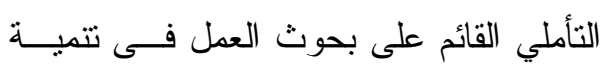

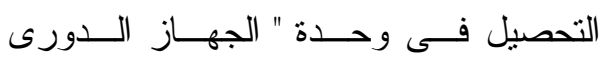

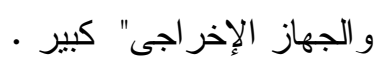

مناقشة وتفسير النتائج المتعلقة بالسؤال الأول :

اتضـح من نتــائج الإجابــة الخاصـــة

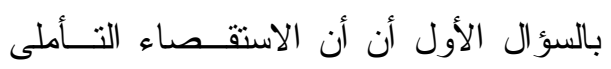

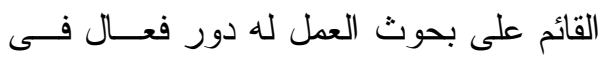

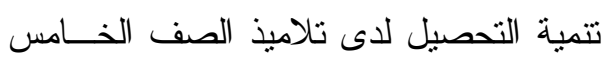
الإبتدائى، وقد ترجع هذه النتائج إلى:

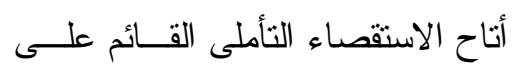

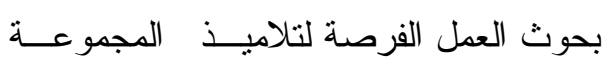

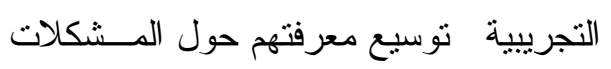

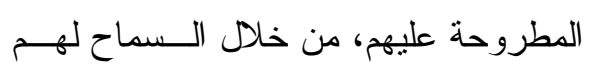
بطر ح الأسئلة، وجمع المعلومات، و اختبـــار

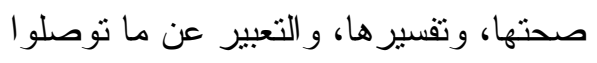

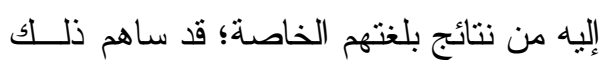

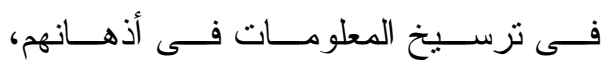

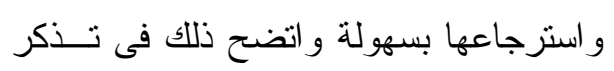

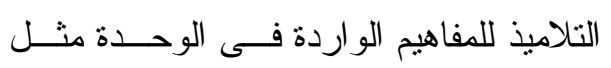

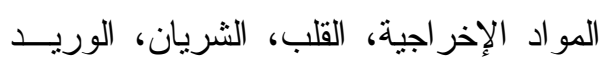

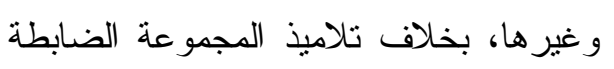

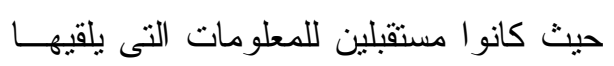


مما يعود بالإيجاب على تتمية التحصيل لدى

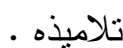

وتتفق نتائج البحث الحالي مع نتـائج

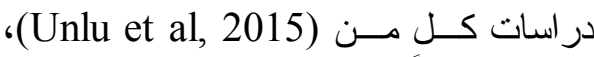
وFernandez, 2017)، و ( رواقــــــة،

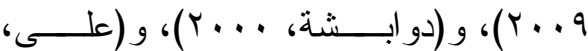
$\cdot(r+1 \mathrm{~V}$

ثانياً: النتائج المتعلقة بالسؤال الثاني:

للإجابة عن السؤال الثانى من أســئلة

البحث، والذى نص على" ما دور الاستقصاء

التأملى القائم على بحوث العمل فــى تتميــة التفكير التأملى لدى تلاميذ المرحلة الإبتدائية

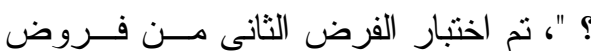
البحث، الذى نص على "توجد فــروق ذات

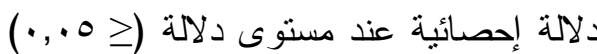
بين متوسطي درجات المجموعة التجريبيـــة و المجموعة الضابطة في التطبيــق البعـــي دري

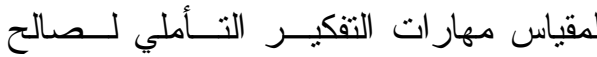

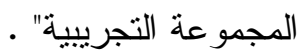

لاختبار هذا الفــرض تــم اســتخدام

اختبار " ت " للمجموعات المستقلة لتحديــــ دلالـــة الفـروق بــين متوســـي درجــات المجموعة التجريبية و المجموعة الضابطة في التطبيق البعدي لـمقياس مهــار ات التفكيـر التأملي، ويتضح ذلك من خلال الجدول (9)

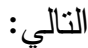

تزتبط بالو اقع الذى يعيشون فيه مما يــدفهم

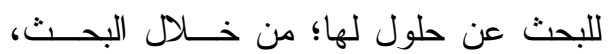

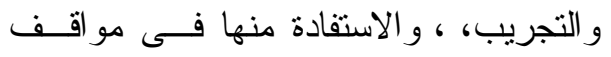

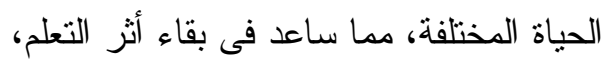
على عكس تلاميذ المجموعة الضابطة يقــدم إليهم المعلم الحقائق جاهزة، و المفاهيم مجردة

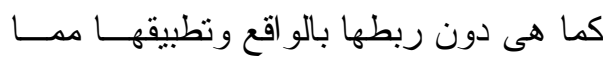
أدى إلى تدنى مستوى التطبيق لديهم • كما تضمنت كر اسة نـشناط التناميــذ

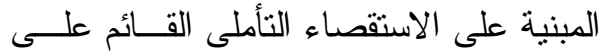
بحوث العمل العديد من الأنــشطة التعليميــة المتتوعة التى تثير انتباه التلاميذ، وتـشجعهم

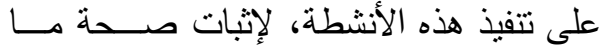
توصلو ا إليه من معلومات، و التوصـل إلــى حلول للمشكلات و الاستفادة منها فى حيــاتهم و اتضح ذلك فى نشاط حساب عـدد دقــات القلب، ونــشاط الــتخلص مــن الفــضلات

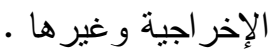

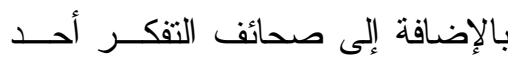

أدو ات بحوث العمل التى ساهمت فى تتميــة

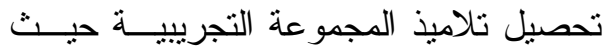

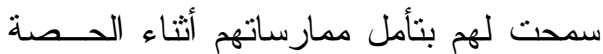

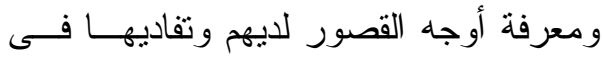
الحصص التالية مما جعلهم أكثــر تفـــاعلاً، وأيضاً كتابة المعلم لصحيفة التفكر الخاصــة به ساعدته فى تحسين ممارساته أثناء الحصة 
جدول(a)

قيمة (ت) للمجموعات المستقلة للالة الفروق بين متوسطي المجموعتين التجريبية والضابطة

\begin{tabular}{|c|c|c|c|c|c|c|c|}
\hline مستوى الدلاية & ل درجات & قيمة & الالحر اف المياري & المتوسط & $\dot{ن}$ & المجموعة & مهارات التفكير \\
\hline \multirow{2}{*}{.6 .1} & \multirow{2}{*}{19} & \multirow{2}{*}{$1 \wedge_{6} \wedge \neg 1$} & $16 \cdot 1$ & 10.91 & $\varepsilon V$ & التجريبية & \multirow{2}{*}{ مهارة التأمل } \\
\hline & & & זו & $\left|r_{6}\right| \mid$ & $\varepsilon \varepsilon$ & الضابطة & \\
\hline \multirow{2}{*}{.6 .1} & \multirow{2}{*}{19} & \multirow{2}{*}{11.071} & $16 \mathrm{~V}$ & Ir.VE & $\varepsilon V$ & التجرييية & \multirow{2}{*}{ مهارة الكشف عن } \\
\hline & & & $1, \varepsilon Y 1$ & 9.97 & $\varepsilon \varepsilon$ & الضابطة & \\
\hline \multirow{2}{*}{.6 .1} & \multirow{2}{*}{19} & \multirow{2}{*}{ IT, YAV } & $.69 . \leq$ & $1 r_{6} \leqslant 0$ & $\leq V$ & التجرييية & \multirow{2}{*}{ مهارة التوصل إلى } \\
\hline & & & 1, YTA & 9.7 & $\varepsilon \varepsilon$ & الضابطة & \\
\hline \multirow{2}{*}{.6 .1} & \multirow{2}{*}{19} & \multirow{2}{*}{$r \leqslant 0 \leqslant V$} & $.6 \leqslant \vee q$ & 1.77 & $\varepsilon V$ & التجريبية & \multirow{2}{*}{ تفسير ات مقنعة إعطاء } \\
\hline & & & $.67 r$ & O.AT & $\leqslant \varepsilon$ & الضابطة & \\
\hline \multirow{2}{*}{$.6+1$} & \multirow{2}{*}{19} & \multirow{2}{*}{$1 T_{6} \leqslant 09$} & .6971 & $\Lambda_{6} 11$ & $\leqslant V$ & التجريبية & \multirow{2}{*}{ مهارة التوصل إلى حلول مقترحة } \\
\hline & & & rTtr & 0,1 & $\leq \varepsilon$ & الضابطة & \\
\hline \multirow{2}{*}{.6 .1} & \multirow{2}{*}{19} & \multirow{2}{*}{ rV.qqu } & r.99V & $0961 \mathrm{~V}$ & $\varepsilon V$ & التجر ييية & \multirow{2}{*}{ الارجة الكلية } \\
\hline & & & r.091 & דז"ז & $\varepsilon \varepsilon$ & الضابطة & \\
\hline
\end{tabular}

حجم التأثير لاستخدام الاستقصائ التأملى القائم

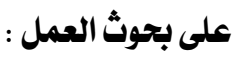

للتعرف على حجم الثأثير في تتميـة

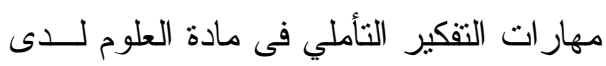

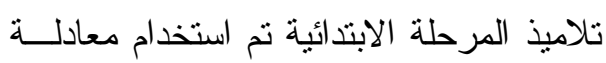

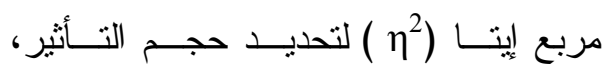

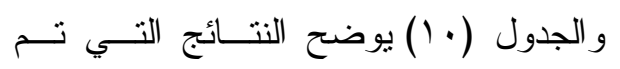

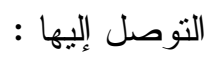

يتضح من الجدول السابق أن جميـع

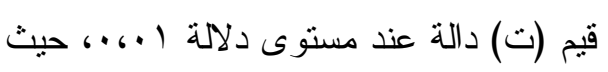

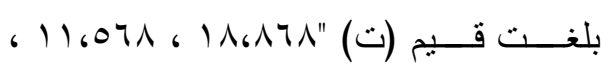

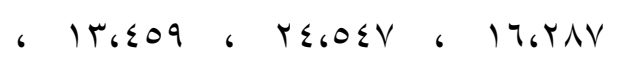

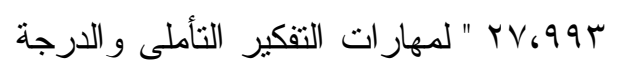

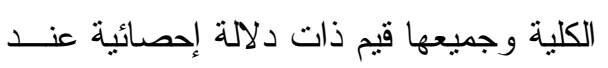

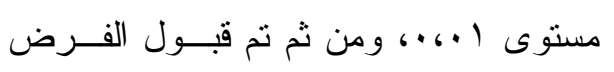
الثانى. 
جدول (·)

حجم تأثير الاستقصاء التأملي القائم على بحوث العمل فى تنمية مهارات التفكير التأملي فى مادة العلوم لاى تلاميذ المرحلة الابتائية

\begin{tabular}{|c|c|c|c|}
\hline حجم التأثير & قيمة (2) ) & قيم (ت) ل مي & مهارات التفكير التأملي \\
\hline كبير & . ‘Ava & 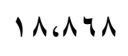 & مهارة التأمل و الملاحظة \\
\hline كبير & . ¿AVT & 11.041 & مهارة الكشف عن المغالطات \\
\hline كبير & .6949 & $17, \mathrm{YNV}$ & مهارة التوصل إلى استتناجات منطقية \\
\hline 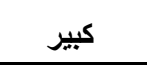 & .095 & $r \leqslant 0 \leqslant v$ & مهارة إعطاء تفسيرات مقتعة \\
\hline كبير & . ^A9V & $1+4809$ & مهارة التوصل إلى حلول مقترحة \\
\hline كبير & 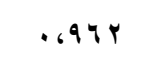 & rv، & الارجة الكلية للمقياس \\
\hline
\end{tabular}

مقترحة ) لــدى تلاميــذ الــصف الخــامس الإبتدائى وقد نرجع هذه النتائج إلى :

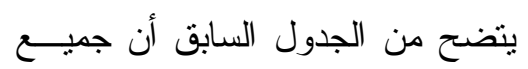

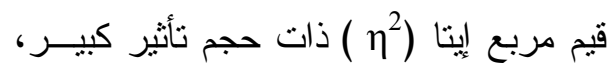

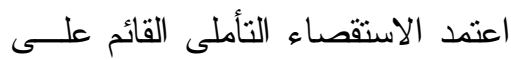

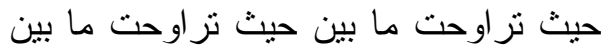

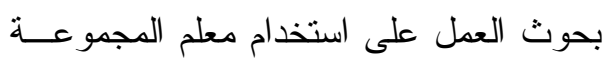

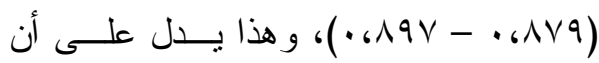

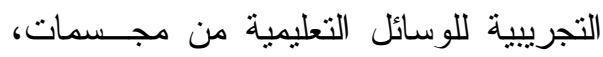

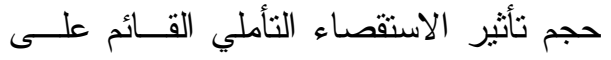
وصور ، وفيديو هات تعليمية تجـــب انتبـاه بحوث العمل فى تتمية التفكير التسأملى فـى لائى

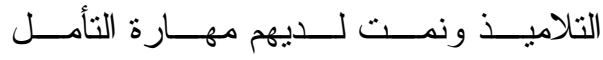

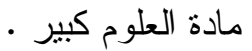
و الملاحظة، واتضح ذلك فى عرض فئسيو مناقشة وتفسير النتائج المتعلقة بالسؤال الثاني: تعليمى يوضح مسار الدم فى كلٍ من الدورة

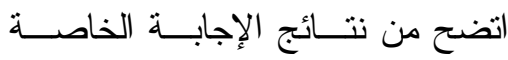

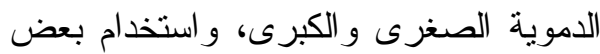

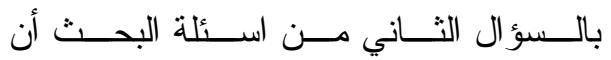
المجسمات متل مجسم القلب، ومجسم الجهاز

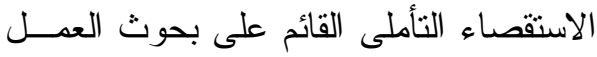
البولى، على عكس المجموعة الضابطة التى التى لله دور فعال في تتميــة مهـار ات التفكيـر افتقرت إلى التتوع فى الوســائل التعليميــة التأملى موضع اهتمام البحث وهى (التأمسل المستخدمة .

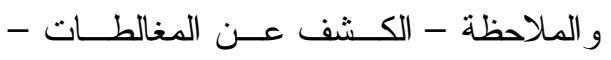

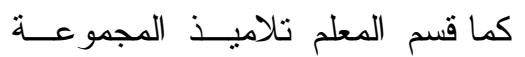
التوصل إلى استنتاجات صحيحة - إعطـــــاء النجريبية إلى مجمو عات صغيرة، وخلق بيئة

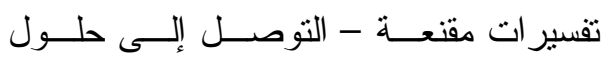


توصلوا إليـــهـ مــن معلومسـات و اختبار هــــا

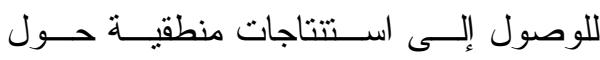

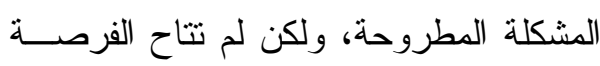

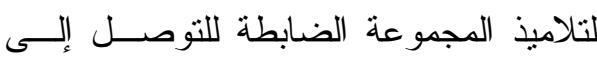
المعلومات و الأفكار بأنفسهم فالمعلم هو ملقن

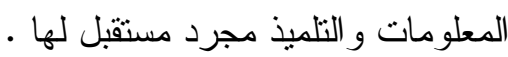
تقديم دروس الوحدة لتلاميذ المجموعة التجريبية فى صورة مشكلات تثيــر انتبـــاه

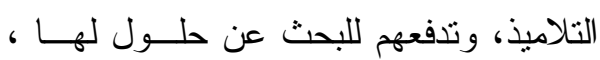

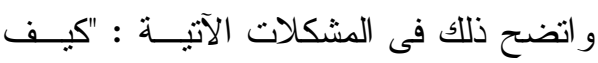
يصل كل من الغذاء المهضوم و الأكسـسجين إلى خلايا الجسم و الفضلات إلــى أعــضـاء الإخر اج؟"، "كيف يتخلص جسم الإنسان مسنـ

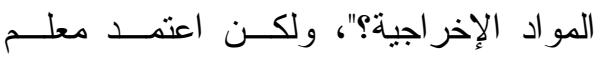
المجموعة الضابطة على الطريقة الاعنيادية وفقاً للاروس الو اردة بالكتاب المدرسى و التى على التى

تعتمد بشكل كبير على الكم وليس الكيف . عزز الاستقصاء التأملى القائم علـى

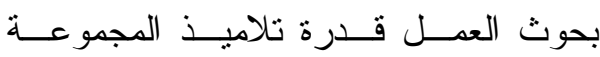
التجريبية للوصول إلـى تعميمسات يمكـن

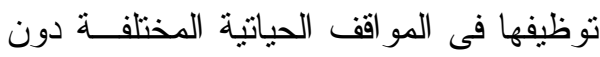

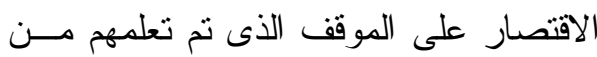

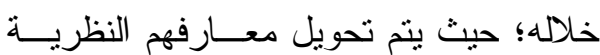

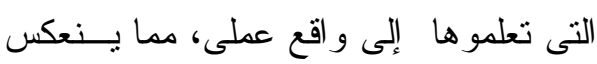

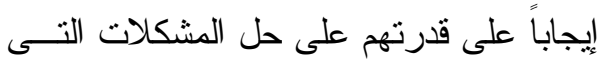

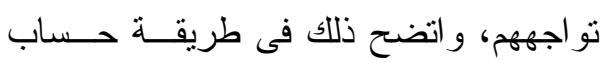

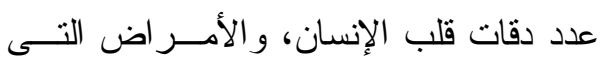

تعلم تعاونية قائمة على المناقتشة، و التفكيــر ،

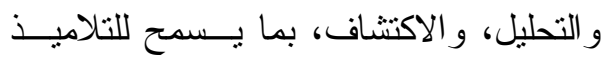

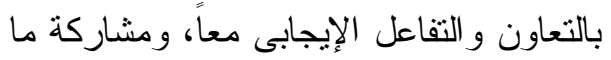
توصلو ا إليه من معلومات مع غيــرهم مسـن

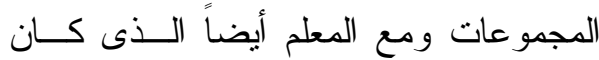

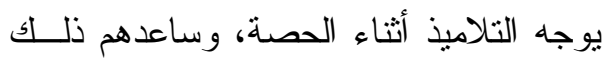
فى تبادل الآر اء و المعلومات، اكتشاف الخطأ منها و استبعادها، و اتضح ذلك مــن خــــله تمييز التلاميذ بين دور كــل مــن الـشـريان

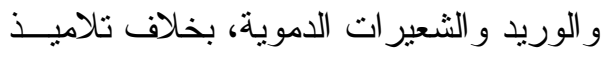

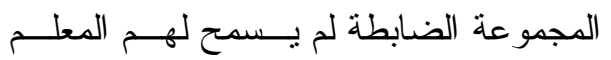

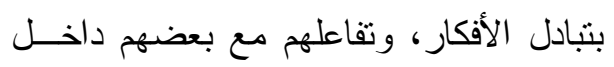

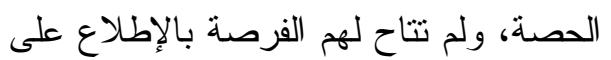
الأفكار المختلفة . واعتمد الاستقصاء التأملى القائم على بحوث العمل بشكل كبير على تأمل تلاميـذذ

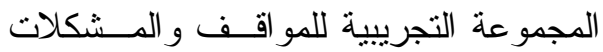

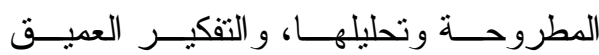

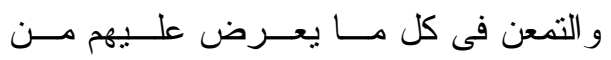
معلومات للاستفادة منها، و استخعاء ما لديهم من معلومات سبق تعلمها فى مو اقف ســابقة

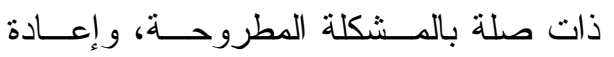

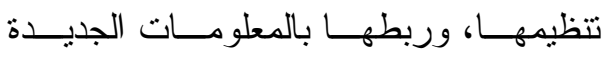

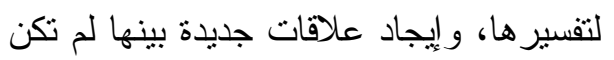

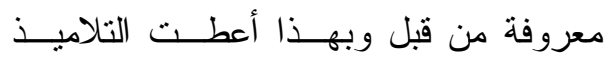

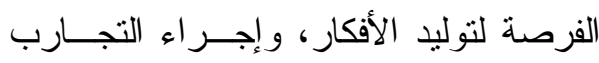

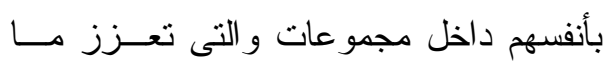




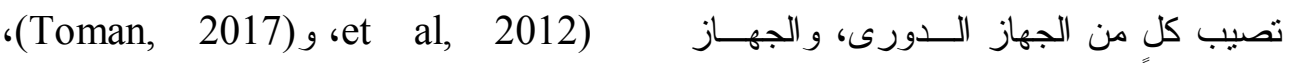

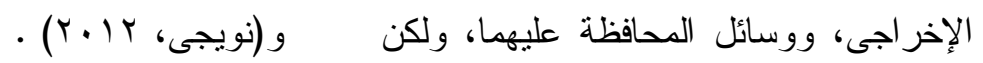
اقتصر معلم المجموعة الضابطة على تقـديم ثالثاً: النتائج التعلقة بالسؤال الثالث: للإجابة عن السؤال الثالــث للبحــثـ

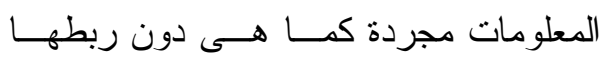
الذي نص على " إلى أى مدى توجد علاقــــة

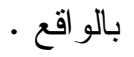

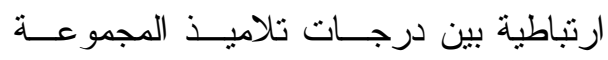

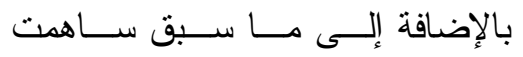

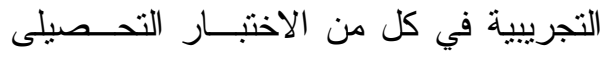
صحائف التفكر لكل من المعلم والتلاميذ فى لإهـ

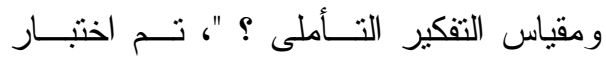
تتمية التفكير التأملى لدى التلامبذ حيث تعتمد الفرض الثالث من فروض الدراســـة الــــي بشكل أساسى على عملية التأمل و الملاحظــــة نص على " توجد علاقــة ارتباطيــة بــين للممارسات أثناء الحصة، و اكتشاف و استتناج

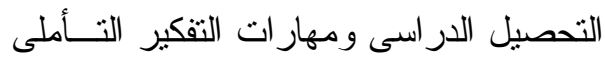

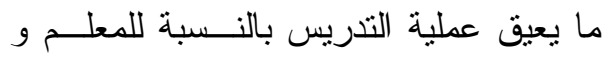
لاى تلاميذ الصف الخامس الابتدائي فى مادة التفاعل أثناء الحصة بالنسبة للطالب، و إيجاد

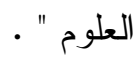

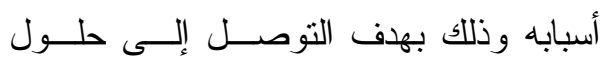
لاختبار هذا الفـرض تــم اســتخدام

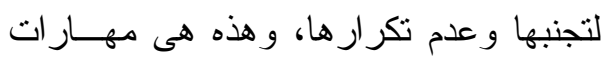

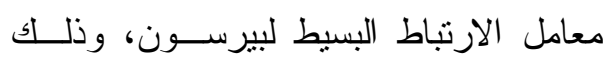

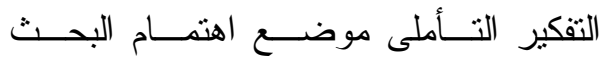

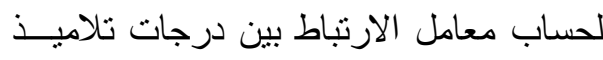
· الحالى

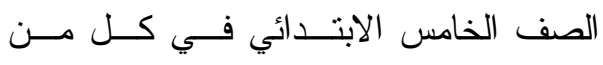
اتفقت تلاك النتيجة مع نتائج در اسات التحصيل الدراسى ومهار ات التقكير التأملى،

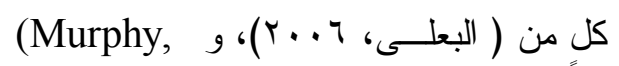
ويبين الجدول (1) التــالي قيمـــة معامـلـل

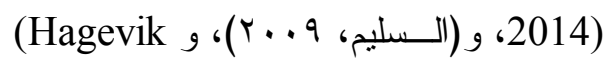
الارتباط ومستوى دلالته : الجنين الجدول

جدول (11)

معامل الارتباط بين درجات تلاميذ الصف الخامس الابتدائي في كل من التحصيل الدرسي

\begin{tabular}{|c|c|c|c|c|c|}
\hline مستوى & قوة العلاقة & اتجاه العلاقة & التحصيلي & معاملات الارتباط & المجموعة \\
\hline. .1 & قوية & موجبة & 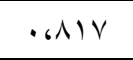 & \multirow{2}{*}{ مقياس مهارات التفكير التأملي } & التجريبية \\
\hline. .1 & متوسطة & موجبة & .6979 & & الضابطة \\
\hline
\end{tabular}




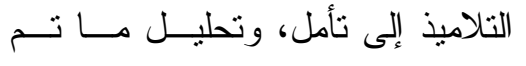

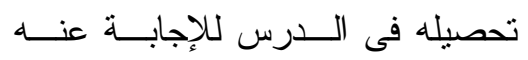

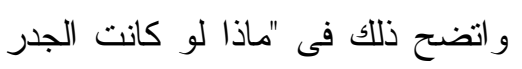

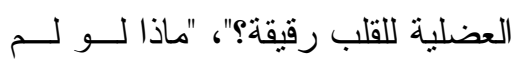

توجد الصفائح الدموية بالدم؟"، "مــاذا

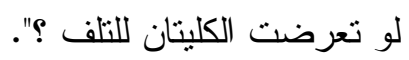

ب- يعزز الاستقصاء التأملى القائم علــى

بحوث العمل قدرة التلميذ على توظيف

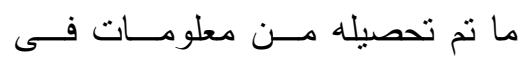

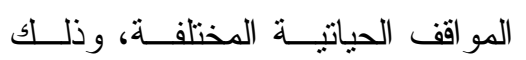

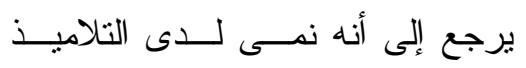

مهار ات التقكير التأملى التى تــساعده إنها.

على تطبيق وتوظيف ما تعلمه .

مناقشة وتفسير النتائج التعلقة بالسؤال الرابع:

نص السؤ ال الر ابع من أسئلة البحـــث

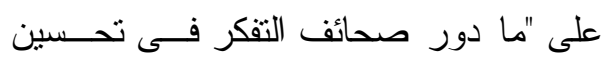

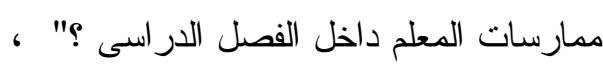

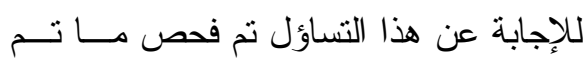

تسجيله فى صحيفة التفكر الخاصة بالمعلمة "

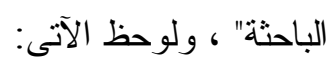

فـى الأســبوع الأول كنـــت أثنــعر

بالخوف الثديد من عدم تقبل التلاميذ لطريقة

الاستقصاء التأملى القائم على بحوث عندم العمل،

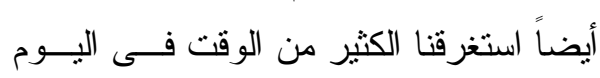

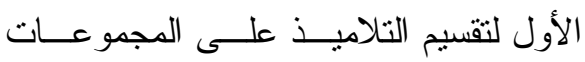

وتوزيع الأدو ار فيما بينهم، ولم أمنح التناميذ الأنيذ

الوقت الكافى للإجابة، بالإضافة إلى شــعور الادور فئر
يتضح أنه بوجد ارنباط طردى بــين

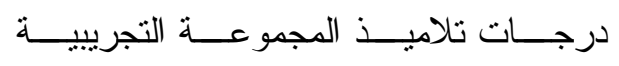

و المجموعة الضابطة في كلٍ من التحــصيل

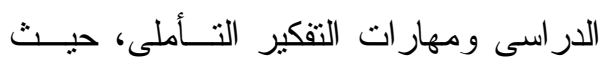

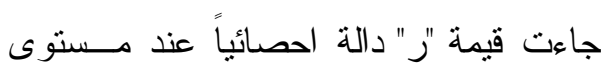

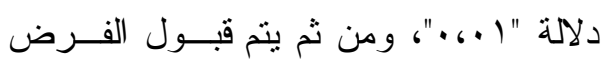

الثالث .

\section{مناقشة وتفسير النتائج التعلقة بالسؤال الثالث:}

اتضح من نتائج الإجابة عن الـسؤ ال

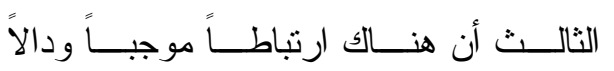

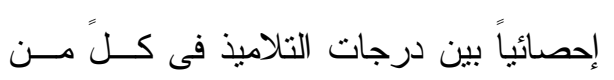

التحصيل و التفكير التأملى، وقد يرجع هــــا

$$
\text { الارنباط إلى : }
$$

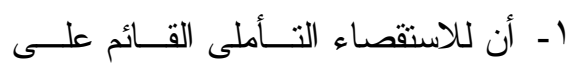

بحوث العمل دور فى تشجيع التلاميذ

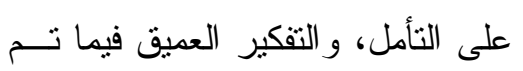

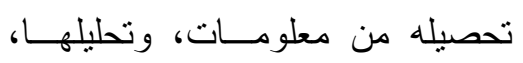

وتفسير ها، للوصول إلى اســنتناجات

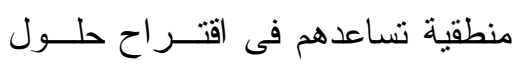

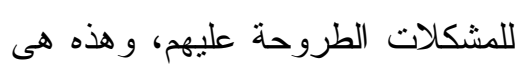

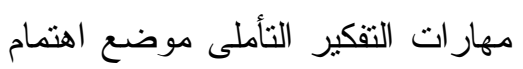

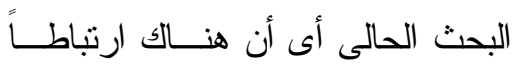

موجباً بين كلٍ من التحصيل و التفكير

• التأملى موحان

Y- تضمن نهاية كل نشاط مــن كر اســـة

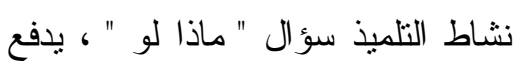


الأول و الثانى، وسعيهم المستمر لتقديم أفضل

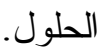

فى الأسبوع الر ابــع و الأخيــر كــان

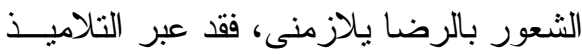

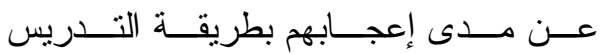

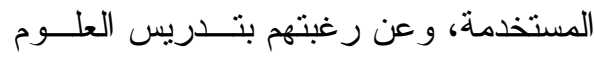
بها، و هذا ما كنت أسعى إليه منذ البداية، فقد

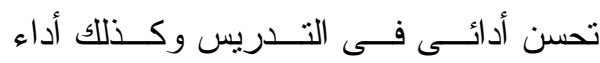
التلاميذ، وذللك بعد أن أدركت أخطائى التـى لـى

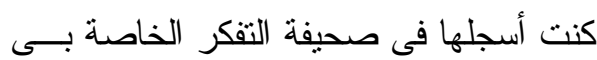

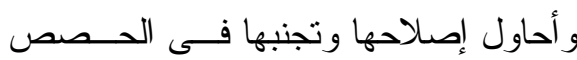
التالية .

مناقشة وتفسير النتائج التعلقة بالسؤال الخامس

نص السؤال الخامس من أسئلة البحث

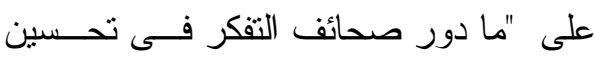

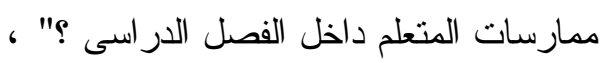

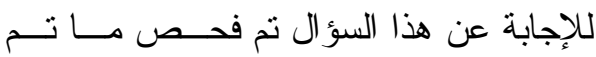

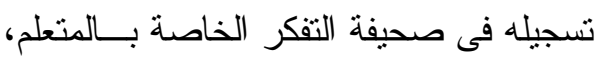

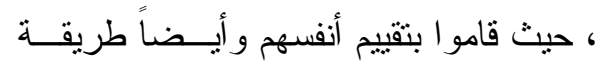

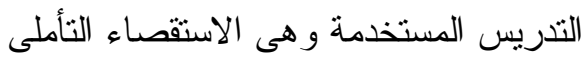

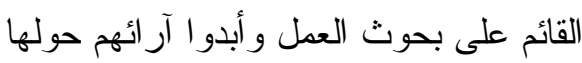

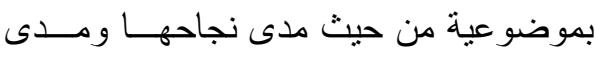
استفادتهم منها، وان كانو ا قد قامو ا بالــدور

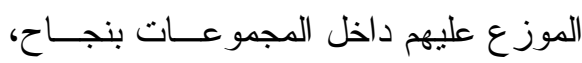
ومدى رغبتهم فى در اسة العلــوم باســـتخدام

هذه الطريقة.
التلاميذ بالغموض حول كيفية كتابة صــحيفة التفكر الخاصة بهم نتيجة لعدم تعرضهم لهذا

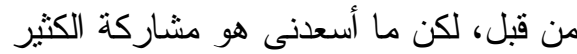

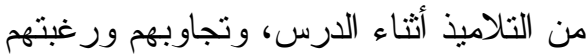
للوصول إلى حلول للمــشكلات المطروحسـة وندة عليهم، وشعور هم بالتحــــى الــذى يـــفعهم

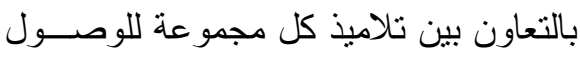
إلى الحل وحصولهم على التعزيز الإيجابى.

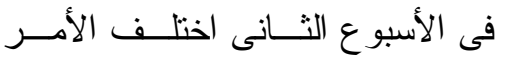

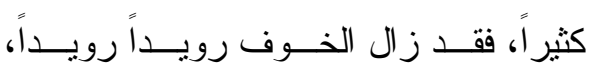
وتمكنت بشكل كبير من السيطرة على تقسيم المجموعات، و استطعت منح التلاميذ الوقت الكافى للإجابة عن التـساؤلات المطروحسـة عليهم، وتحسنت كثير اً عن الأســبوع الأول لأجسابه فى تتفيذ خطوات الاستقصاء التأملى القــائم على بحوث العمل، و لاحظت انعكاس هـــا بالإيجاب على التلاميذ من خلال مسـشاركتهم الفعالة و عدم اهدار هم للوقت، وبذل قصارى لإنى

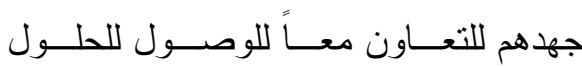
بسهولة. فى الأسبوع الثالث شعرت بقدر كبير

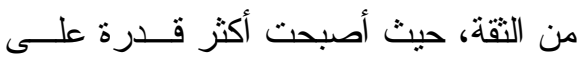

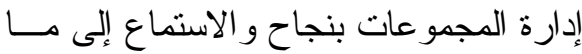
توصلو ا إليه من نتائج ومناقـشتنهم أيــضاً،

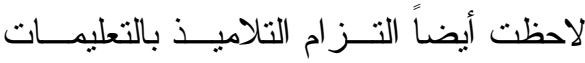
بشكل أفضل، وتحسن أدائهم عن الأسبو عين 
للمشاركة الفعالة، وتقديم المزيد من الإجابات

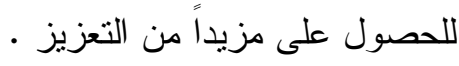

توصيات البحث

فى ضوء ما أسفر عنه البحث مسن نتــائج

يمكن تقديم التوصيات التالية :

ا ـ تأهيل المعلمين قبل الخدمـــة وأثتــــاء

الخدمة لاستخدام بحوث العمـلـل مــن فئن

خلا إجر اء دور ات تدريبية بـصورة

دورية، وذللك لما لبحوث العمل مــن دورن

دور فعال فى تحسـين الممارسـات

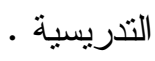

r- مر اعاة مخططى المناهج بناء الأنشطة

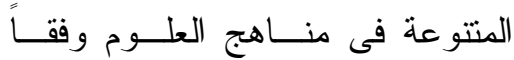

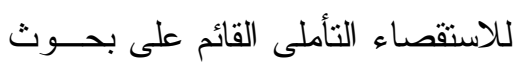

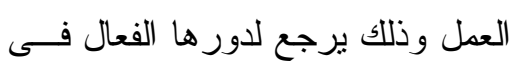

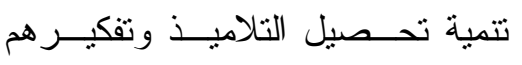

$$
\text { التأملى }
$$

r- عقد دورات تدريبية للمعلمين لتدريبهم

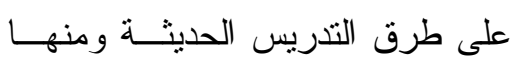

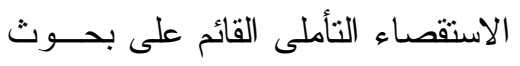

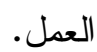

\section{ثالثاً: مقترحات البحث:}

فى ضوء نتائج البحث الحالى أمكن اقتراح

الار اسات الآتية :

1- الاستقصاء التأملى القائم على بحــوث

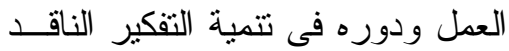

لوحظ قدرتهم على وصف ما شعروا

به أثناء فترة التدريس، ففى صحيفة التقكـــر

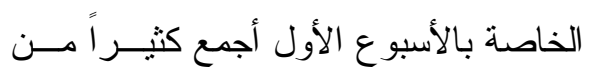

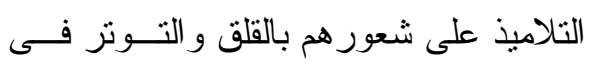

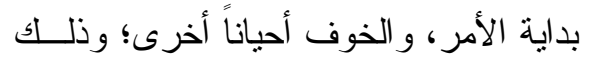
لعدم استخدامهم لهذه الطريقة فى در اســتهم من قبل، ولكن فى الثلاث أســابيع التاليـــة، عبرو ا عن شعور هم بالسعادة لاستخدام هـــه وله

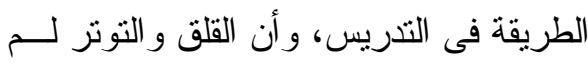

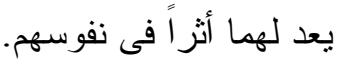
كما لوحظ انهم قد قامو ا بالتأمل فـى في ممارساتهم بشكل كبير ، فالبعض فى الأسبوع

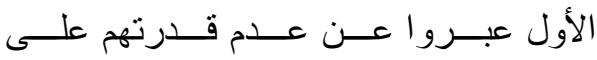
المشاركة، و استغر اقهم للكثير من الوقت فى الأى

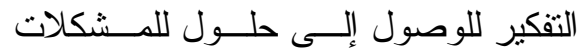
المطروحة عليهم، ولكن فى الثنلاث أســابيع التالية عبرو ا عن مدى تحسنهم، قدرتهم على حل المشكلات المطروحة عليهم باســتخدام

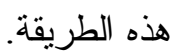
و أيضناً عبر الكثير من التلاميذ عـن

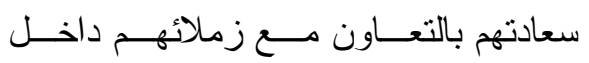

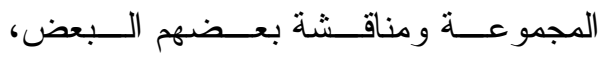
ومشاركتهم للأفكار معاً، و استمتاعهم بالقيـام بعن

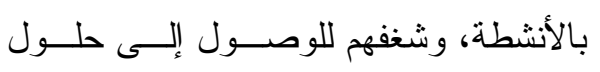

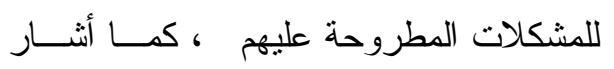
البعض إلى سعادتهم من أســاليب التعزيــز

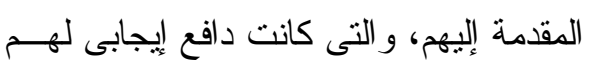




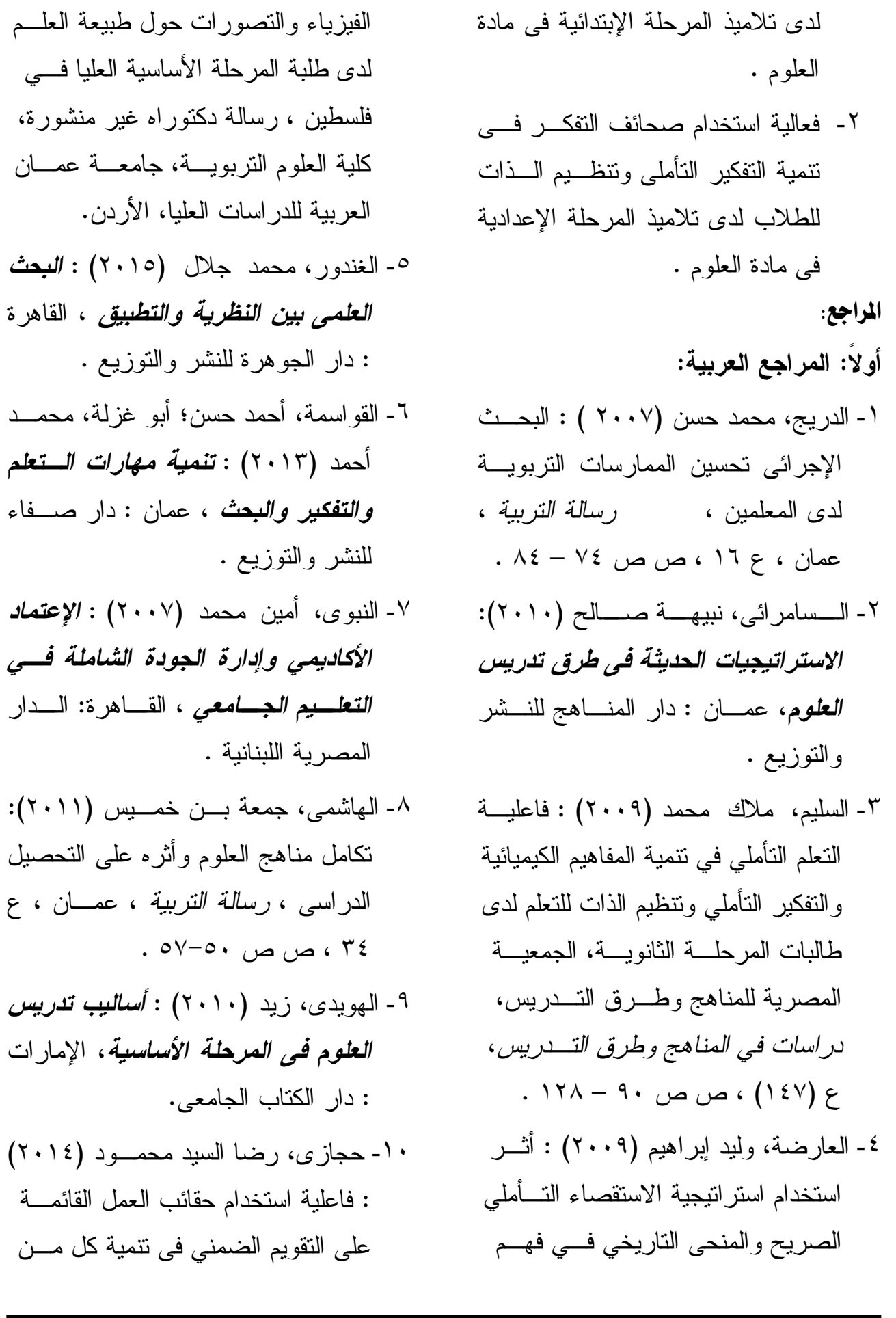


وتظوير المؤسسة التريوية ، القاهرة :

$$
\text { دار النشر للجامعات . }
$$

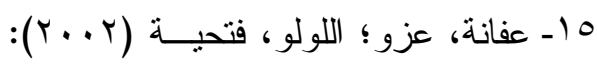

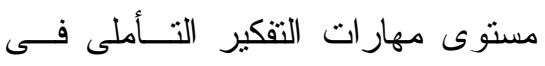

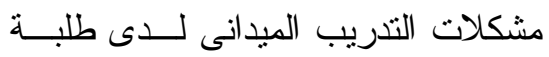

كلية التربية بالجامعة الإسلامية بغــزة ،

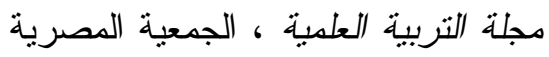

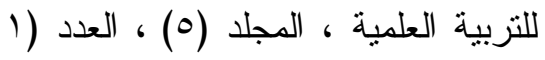

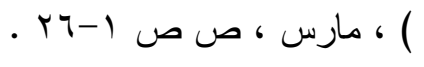

T 1 - على، جمال محمد أحمد محمد (Y. Y (Y)

: فعالية استخدام البحث الإجر ائى فـى التى

تتمية مهار ات التفكير التأملى و التحصيل التجى التى

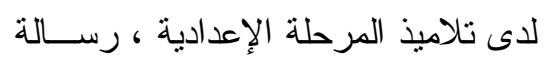

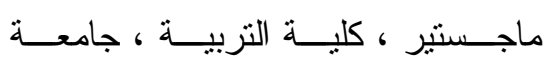

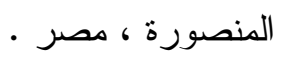

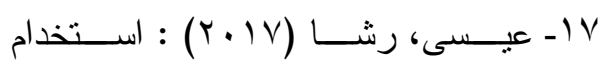

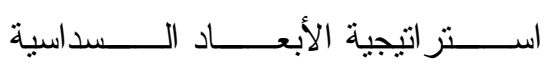
PDEODE

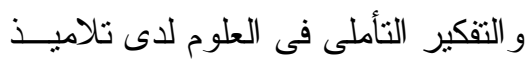

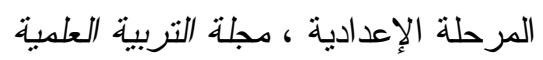

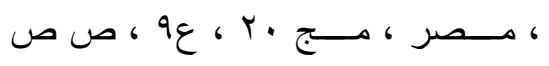
$.99-71$

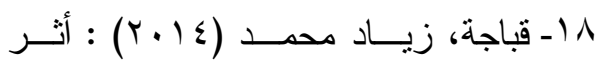
استخدام استر اتيجية الاستقصاء التــأملي

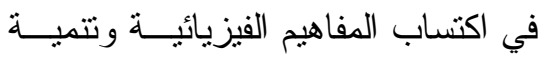

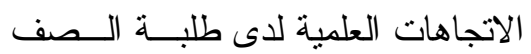

$$
\begin{aligned}
& \text { التفكير التأملي و التحصيل والاتجاه نحو }
\end{aligned}
$$

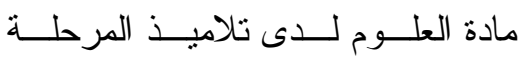

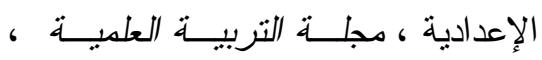

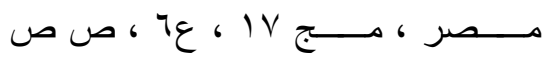

$$
\begin{aligned}
& \text {. } r \leq r-191
\end{aligned}
$$

II - سحتوت، إيمان محمد؛ جعفر، زينــب

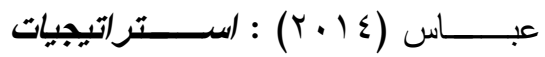

التلدريس الحديثة، الـسعودية: مكتبــة

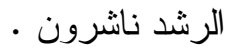

T ( - صالح، مدحت محمد حسن (T/ (r) :

فاعلية نموذج اديسون للتعلم مــن أجــل مدلـ

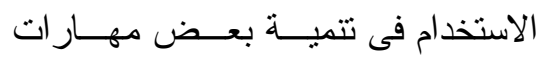

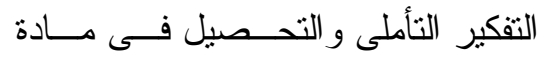

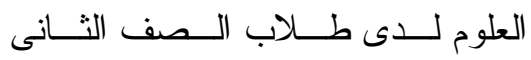

المتوسط بالمملكة العربية الـسعودية ،

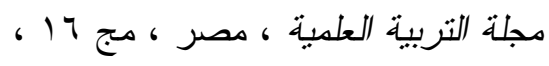

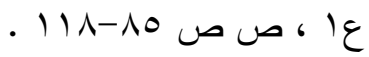

rا - عبود، سهام عبد الأمير (10 + ب) : أثز

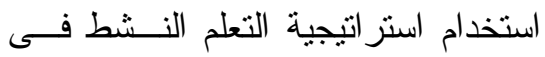

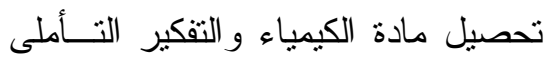
لاى طالبات الصف الثانى المتوســ ، مجلة الأستاذ ، كليــة التربيــة للعلــوم

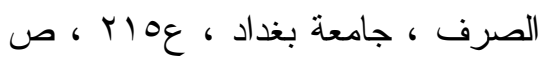
ص

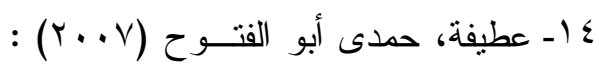
بحوث العمل طريق إلى تمهين المعلــــ 
through reflective inquiry, Problems of Education in the $21^{\text {st }}$ Century, 63,29-39.

23- Ebbutt, D. (1985). Educational action research: Some general concerns and specific quibbles, Issues in educational research: Qualitative methods, 152-174.

24- Fernandez, F. B. (2017). Action research in the physics classroom: the impact of authentic, inquiry based learning or instruction on the learning of thermal physics. Asia-Pacific Science

Education, 3(1), 3.

25- Halim, L., Buang, N. A., \& Meerah, T. S. (2010). Action research as instructional supervision: Impact on the professional development of university based supervisors and science student teachers, Procedia-Social and Behavioral Sciences, 2(2), 2868-2871.

26- Hiebert, J. \& Carpenter, T. P. \& Fennema, E. \& Fuson, K. \& Human, P. \& Murray, H. \& Olivier, A. \& Wearne, D. (1996). Problem solving as a basis for reform in curriculum and instruction: The case of mathematics. Educational researcher, 25(4), 12-21.

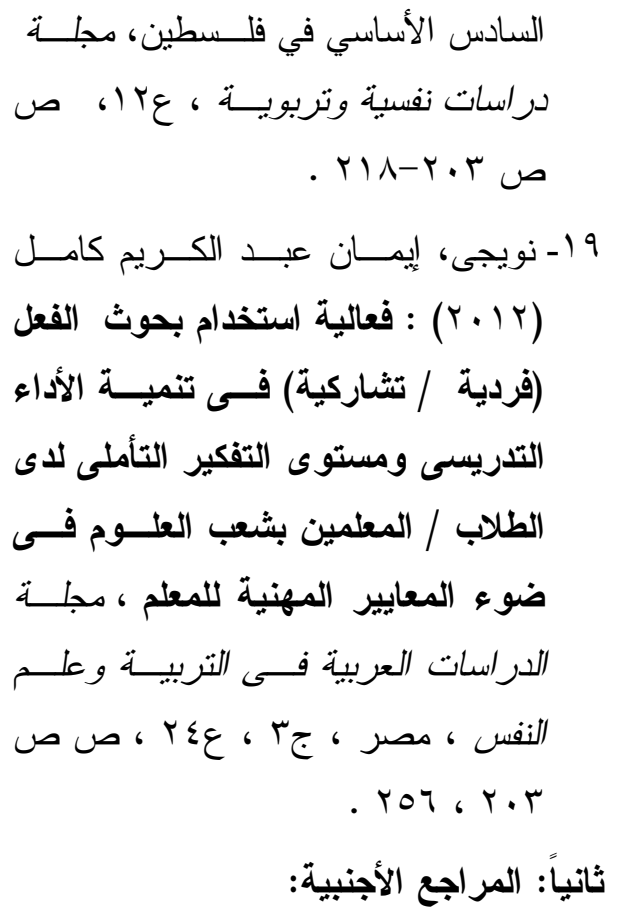

20- Cengiz, C., \& Karatas, F. O. (2015). Examining the effects of reflective journals on preservice science teachers' general chemistry laboratory achievement. Australian Journal of Teacher Education (Online), 40(10), 125.

21- Chien, C. \& Lin, L. \& Yu, K. (2013). A Reflective SelfInquiry into My Teaching Practices with Non-English Major Technological University Students', Canadian Journal of Action Research, 14 (3): 59-71.

22- Dimova, Y., \& Kamarska, K. (2015). Rediscovering John Dewey's model of learning 
introduce action research to pre service teachers. Action Research, 6(1): 7-28.

32- Murphy, K. R. (2014). The Effect Of Reflective Practice On High School Science Critical and Reflective thinking. Doctoral dissertation. Instructional Leadership. Western Connecticut State University.

33- Nunan, D. (1992). Research methods in language learning. Cambridge, UK: Cambridge University Press.

34- Töman, Ufuk (2017). Investigation to Improve the Process of Pre-service Teachers' Reflective Thinking Skills through an Action Research. Universal Journal of Educational Research. 5(9). Pp. 1535-1548.

35- Unlu, Z. K., Dokme, I., \& Tufekci, A. (2015). An action research on teaching science through technology supported inquiry-based learning: a pilot study. Procedia-Social and Behavioral Sciences, 186, 4652.

36- Vaino, K. (2013). A case study approach to effect change of chemistry teacher beliefs for enhancing students' scientific literacy. Doctoral dissertation. University of Tartu, Estonia.
27- Hudak, M.

(2013).

Professional Development

Plus: Rethinking Professional

Learning.

Doctoral dissertation. Arizona State University.

28- Johnson, Ruth S. \& Mims, J. Sabrina \& Nichols, Adelaide. (2010). Developing Portfolios in Education: A Guide to Reflection, Inquiry, and Assessment. $2^{\text {nd }} \quad$ Edition. California . SAGE Publications.

29- Jonsson, F. (2009). " Det här är riktig NO": En aktionsforskningsstudie Om elevintresse och måluppfyllelse vid undersökningsbaserat lärande $\mathrm{i}$ NO. Examensarbete $15 \mathrm{hp}$. Faculty of Humanities and Social Sciences. Växjö University. Swedish.

30- Kishfe, R. and Abd- Elkhalick, F. (2002). Influence of explict and reflective versus implicit inquiry-oriented instruction on sixth graders views of nature of science. Journal of Research in Science Teaching. 39(7). 551-578.

31- Kitchen, J. \& Stevens, D. (2008). Action research in teacher education: Two teacher-educators practice action research as they 
Behavioral Sciences, 47, 739744.

38- Yost, D. S., Sentner, S. M., \& Forlenza-Bailey, A. (2000). An examination of the construct of critical reflection: Implications for teacher education programming in the 21 st century. Journal of teacher education, 51(1), 3949.
37- Vaiyavutjamai, $\quad$ P. $\quad \&$ Charoenchaia, S. \& Ponmanee, S. \& Danpakdee, A. \& Chotivachira, B. \& Kamol, N. \& Pankaew, P. \& Warotamawit, V. \& Sitthiwong, W. (2012). Collaborative action research to promote reflective thinking among higher education students. Procedia-Social and 